\title{
La villa y la encomienda de Calatrava la Vieja en la Baja Edad Media
}

\author{
EnRiQue Rodríguez-Picavea Matilla*
}

\begin{abstract}
RESUMEN
Este articulo analiza el período menos conocido de la historia de Calatrava la Vieja, un lugar clave en la frontera entre Castilla y al-Andalus hasta la segunda década del siglo xim. Precisamente nuestro trabajo se inicia en ese momento, cuando la historia de la villa experimenta un cambio sustancial como consecuencia del traslado de la sede de la Orden de Calatrava a un nuevo emplazamiento más meridional, que a partir de entonces sería conocido como Calatrava la Nueva. Asistimos asi

a la prolongada decadencia de la primitiva Calatrava, al desarrollo de una encomienda de la citada Orden militar y a la definitiva despoblación de la villa y su conversión en rentable dehesa de explotación ganadera. Además se estudian especificamente las

actividades económicas y la peculiar organización eclesiástica. El trabajo se completa con la edición de diez
\end{abstract}

\section{ABSTRACT}

This article analyses the least known historical period of Calatrava la Vieja, a key place in the boundary between Castilla and Al-Andalus, until the second decade of the XIII th century. It is in that precise moment where this report starts, just when the history of the city experiments a substantial change due to the move of the Order of the Knights of Calatrava headquarters to the south, to a place since then known as Calatrava la Nueva. It is observed, therefore, the prolonged decline process of the old Calatrava, as well as the development of an «encomienda» or concession of the mentioned Military Order and to the total depopulation of the city and its convertion into a productive animal farm. In addition, the economic activity and the particular ecclesiastic organization are specifically studied. This report ends with the issue of ten documents about the

* Universidad Autónoma de Madrid. 
documentos relativos a la encomienda de Calatrava la Vieja en el tránsito del siglo $\mathrm{XV}$ al $\mathrm{XV}$. «encomienda» of Calatrava la Vieja between the $x V$ th. and the $x V I$ th. century.

El 1 de julio de 1212, en el transcurso de las operaciones militares que precedieron a la batalla de las Navas de Tolosa, la villa de Calatrava fue definitivamente incorporada al dominio cristiano e inmediatamente entregada por Alfonso VIII a la Orden calatrava ${ }^{1}$. Después de $1214^{2}$, probablemente en 1217, pero con seguridad antes de $1221^{3}$, el convento principal de los calatravos y residencia del maestre fue trasladado a un nuevo emplazamiento más meridional ${ }^{4}$, situado probablemente en la fortaleza de Dueñas ${ }^{5}$-recuperada por Alfonso VIII en 1213 y cedida a los freires calatravos ${ }^{6}$-, o en sus inmediaciones, pero en cualquier caso ubicada frente al castillo de Salvatierra, que permanecía todavía bajo dominio musulmán. El lugar sería conocido a partir de entonces con el nombre de Calatrava la Nueva, mientras que la primitiva sede tomaría el nombre de Calatrava la Vieja, para distinguirla de la anterior.

Son varias las razones que pueden apuntarse para explicar el traslado de la sede calatrava: sanitarias (por la insalubridad del emplazamiento de Calatrava la Vieja), estratégicas (la nueva situación de la frontera castella-

Roderici XIMEnNI de Rada, Opera Omnia. Pars I. Historia de Rebvs Hispanie sive Historia Gothica, cura et stvdio de Juan Fernández Valverde, Corpus Christianorum. Continuatio Mediaevalis, LXXII, Tvrnholti, 1987, Libro VIII, Capítulo VI. Cfr. Rodrigo JIMÉNEZ DE RADA, Historia de los hechos de España, introducción, traducción, notas e índices de Juan FERNÁNDEz VALVERDE, Madrid, 1989, pág. 314.

2 Fecha en la que se documenta la presencia de los calatravos en su villa fundacional, concretamente se menciona la presencia en Calatrava del «cabildo de los frailes». Vid. Ibid., págs. 327-328.

3 La primera vez que la nueva sede de la Orden aparece documentada con la denominación de "Calatrava la Nueva" es en 1221. Vid. Joseph F. O'CALLAGHAN, "Sobre los orígenes de Calatrava la Nueva", Hispania, 23 (1963), 494-504.

4 Según el historiador Francisco de Rades y Andrada, en 1217 el maestre Martín Fernández de Quintana decidió trasladar la sede de la Orden y su convento principal a una fortaleza situada varios kilómetros al Sur, muy próxima al castillo de Salvatierra, que permanecía todavía en poder de los musulmanes. Vid. F. RAdes y ANDRADA, Chronica de las tres Ordenes y Cavallerias de Sanctiago, Calatrava y Alcantara, Toledo, 1572, (ediciones facsímiles, Barcelona, 1980 y Valencia 1994), Chronica de Calatrava, fol. 33.

5 La identificación entre las dos fortalezas procede de la Crónica latina de los Reyes de Castilla (ed. Luis Charlo BrEA, Universidad de Cádiz, 1984, pág. 36) y ha sido aceptada después por casi todos los historiadores.

- Roderici XIMEN! de RADA, Historia de Rebvs Hispanie, Libro VIII, Capítulo XIII; JIMÉNEZ DE RADA, Historia, pág. 326. 
no-andalusí), eclesiásticas (el monopolio que el arzobispo de Toledo tenía sobre las rentas de las iglesias de Calatrava la Vieja) y socioeconómicas (para impulsar de forma más directa la organización del sector meridional del Campo de Calatrava).

En cualquier caso, el traslado de la sede de la Orden de Calatrava tuvo unas consecuencias trascendentales para la villa primitiva. Por eso en este trabajo pretendemos analizar el período menos conocido de la historia de Calatrava la Vieja, el que se inicia en la segunda década del siglo XIII y culmina en el siglo $\mathrm{XV}$. Un período en el que asistimos a la progresiva decadencia de la villa y al mismo tiempo a la creación y posterior consolidación de una encomienda de la Orden de Calatrava.

\section{DECADENCIA DE LA VILLA Y ORIGGENES DE LA ENCOMIENDA DE CALATRAVA LA VIEJA}

En efecto, el traslado de la sede calatrava marcó definitivamente la historia posterior de su villa fundacional. La población no abandonó Calatrava la Vieja, pero la villa inició una decadencia imparable, agravada por sus condiciones de insalubridad. El papel de la villa como lugar de referencia en la zona central del Campo de Calatrava decreció considerablemente durante la segunda mitad del siglo XIII, cuando la fundación de Villa Real le arrebató el escaso protagonismo que todavía le quedaba, provocando además el desvío del camino de Córdoba a Toledo.

Sin embargo, parece que ya en el siglo Xill pudo constituirse la encomienda de Calatrava la Vieja como la mejor forma de canalizar la explotación de la villa y su territorio circundante a favor de los freires calatravos. Desconocemos la fecha exacta de la fundación de la encomienda. El primer comendador que tenemos documentado es frey Pedro Fernández de Carvallo, que según Rades ocupó el cargo durante el maestrazgo de Garci López de Padilla (1296-1329) ${ }^{7}$. Basándose únicamente en este dato, Manuel Corchado situó el origen de la encomienda de Calatrava la Vieja en 1296. Sin embargo, tal dato no es argumento suficiente. Nada seguro podemos afirmar al respecto, pero resulta hasta cierto punto llamativo que la encomienda se funde a finales del siglo XIII, cuando Calatrava la Vieja se encuentra inmersa en un proceso de decadencia. A modo de hipótesis, podemos aventurar que la encomienda pudo crearse como respuesta a la fundación de Villa Real. Si así fuera, cuando en diciembre de 1267 se celebró en

\footnotetext{
7 RAdes, Chronica de Calatrava, fol. 52 v.
} 
Calatrava la Vieja la reunión entre el maestre Juan González, acompañado de los comendadores y freires de su Orden, y los alcaldes y el concejo de Villa Real ${ }^{8}$, la encomienda ya estaría constituida. De ser así, probablemente la concordia se habría celebrado en la residencia del comendador, que debía ser todavía la antigua fortaleza de Calatrava. En la entrevista se trató sobre los fueros de Villa Real y los lugares de la Orden.

Pero, al margen de la fecha de la constitución de la encomienda, la concordia de 1267 tiene una gran importancia porque nos indica que al comienzo del último tercio del siglo XIII Calatrava la Vieja todavía conservaba cierta importancia como lugar de referencia en la zona. Habían transcurrido pocos años desde la fundación efectiva de Villa Real y las funestas consecuencias que tal hecho iba a traer para Calatrava la Vieja todavía no se habían dejado sentir con fuerza. Sin embargo, el acuerdo de 1267 marca un punto de llegada para Calatrava la Vieja y un punto de partida para Villa Real. A partir de entonces asistimos a la caída de la primera y al ascenso y consolidación de la segunda. Ya no volvemos a tener ninguna referencia - al menos no las conocemos - sobre la celebración de acuerdos o reuniones de la Orden en Calatrava en su villa fundacional. Al año siguiente de la mencionada concordia, en 1268, tuvo lugar un nuevo encuentro entre los representantes de la Orden y los del concejo de Villa Real, pero esta vez se celebró en Miguelturra ${ }^{9}$.

En cualquier caso, es evidente que nos faltan datos. Los pocos que tenemos nos indican la cesión por parte de la Orden de algunos bienes cercanos a Calatrava la Vieja. Es el caso de la azuda del Emperador, que en julio de 1219, curiosamente poco después de que Calatrava la Vieja dejase de ser la sede de la Orden, el maestre Gonzalo Yáñez y el comendador mayor Gonzalo González la cedieron con carácter vitalicio a Juan Pono y a su mujer doña Eulalia ${ }^{10}$. Casi medio siglo después, en abril de 1267, el maestre calatravo Juan González concedió en prestimonio vitalicio a Rodrigo Martínez de Mosquera, arcediano de Calatrava, entre otros bienes, los molinos, la labor del pan de la azuda del Emperador ${ }^{11}$, y varios

8 E. Bernabeu, Inventario del Excmo. Ayuntamiento de Ciudad Real, hecho en 1591 (transcripción), Ciudad Real, 1952, pág. 15; L. DELGADO MERCHÁN, Historia documentada de Ciudad Real. La judería, la inquisición y la Santa Hermandad, 2. a ed., Ciudad Real, 1907, págs. 48 y 83.

g Ibid.

${ }_{10}$ Archivo Histórico Nacional (AHN), Órdenes Militares (OO.MM.), Calatrava, carp. 458, $n .{ }^{\circ}$ 82; ibid., sign. $1342 \mathrm{c}$, fol. 93

11 La azuda del Emperador se encontraba próxima a Calatrava, sobre el cauce del Guadiana, al sur del anejo de Peralvillo, perteneciente actualmente al término de Miguelturra. Su localización en Mapa Topográfico Nacional y Mapa Militar de España, Escala 1:50.000, Hoja 759; Cartografía Militar de España, Escala 1:10.000, Hoja, 18-30-19. 
yugos de bueyes con "su sementera completa» ${ }^{12}$. Pocos años antes, en 1259, un freire de la Orden de Calatrava, frey Gonzalo Suárez, entregaba a esta institución el molino del Emperador, situado sobre la ribera del Guadiana ${ }^{13}$. No sabemos si este molino entraba dentro del conjunto de la azuda o era considerado como un elemento aparte.

Por otra parte, en la explotación del territorio de la villa continuaban interesándose algunos particulares al margen de la Orden de Calatrava. En diciembre de 1257, doña Inés arrendó a don Gonzalo Ruiz todo cuanto tenía en Calatrava la Vieja y su término, con los molinos que tenía en el Guadiana, la azuda de doña Olalla y una mora, por un período de cuatro años a cambio de 500 maravedís alfonsinos ${ }^{14}$.

Paralelamente, y a lo largo del siglo xill, en la zona cercana a Calatrava la Vieja se produjo un proceso de consolidación de nuevos núcleos poblacionales, que fueron configurando un término propio en perjuicio del de Calatrava, cada vez más reducido. Así en la zona septentrional, Malagón tenía fortaleza, villa y encomienda propia desde el siglo XII. A partir del siglo XIII se aprovechó de la decadencia de Calatrava para explotar su estratégica situación en el camino de Córdoba a Toledo, pues viniendo de esta última ciudad se hacía noche en Malagón después de la segunda jornada de viaje ${ }^{15}$. Por el sector oriental, desde la segunda mitad del siglo XIII destacaba la pujanza de Daimiel; en 1268 el maestre Juan González señaló los términos del amplio territorio concedido a esta villa: desde la senda de La Pollina, donde lindaban con el término de Barajas, se dirigían hasta el término de Torroba, para continuar por los límites de Moratalaz hasta alcanzar los Ojos del Guadiana, siguiendo entonces el curso del río hasta la dehesa de Zacatena, donde la delimitación proseguía hasta la senda de la Pollina ${ }^{16}$. En la zona meridional se configuraba Miguelturra, a la que entregó fuero breve ${ }^{17}$ el

12 AHN, OO. MM., carp. 459, n. ${ }^{\circ} 119$; ibid., sign. 1344 c, fol. 28; Real Academia de la Historia, col. Salazar, sign. 9-614, fol. 164 v-165 v.

13 Vid. AHN, OO.MM., Índice 56, pág. 93; I. HeRVÁs y F. Galiano, «Documentos originales del Sacro Convento de Calatrava que atesora el Archivo de Hacienda en Ciudad Real», Boletín de la Real Academia Historia, 20 (1892), pág. 557.

14 Archivo de la Catedral de Toledo, sign. A.11.F.1.2.

15 Manuel CoRCHADO, Estudio histórico-económico-jurídico del Campo de Calatrava, 3 vols., Ciudad Real, 1982-1983-1984, III, pág. 287.

16 El documento lo conservaban en 1575 los vecinos de Daimiel inserto en una carta ejecutoria de Felipe II. Vid. Carmelo VIÑAS y Ramón PAZ, Relaciones de los pueblos de España ordenadas por Felipe II. Ciudad Real, Madrid, 1971, págs. 235-236.

17 Un estudio sobre este documento en José Manuel OCAÑA BARBA, «Los privilegios medievales de Miguelturra: la Carta Puebla y la posterior ampliación de los privilegios», en Ricardo IZQUIERdo BENITO y Francisco RuIz GómEz (Coordinadores), Actas del Congreso Internacional conmemorativo del VIII centenario de la Batalla de Alarcos, Cuenca, 1996, 367-388. 
maestre Martín Rodríguez (1237-1240), señalando los términos de la aldea fronterizos con los de Calatrava la Vieja: por el camino que va a la Membrilla e parte con Calatrava la Viexa ${ }^{18}$. Por las mismas fechas, se consolidaba, al noreste de Miguelturra, la aldea de Carrión, que en el mencionado ordenamiento foral aparece con términos propios, limítrofes con Miguelturra por la zona de un encinar, convertido en dehesa del propio concejo de Carrión ${ }^{19}$. Por último, en la zona occidental, la creación del concejo de Villa Real -jurídicamente realizada en 1255, aunque probablemente no materializada hasta 1262 - propició la consolidación de un alfoz de realengo, con términos propios y limítrofes con los de Calatrava la Vieja ${ }^{20}$.

En consecuencia, los términos de Calatrava la Vieja quedaron reducidos en el siglo xill a un territorio que en líneas generales se extendía por el cauce del Guadiana desde la azuda del Emperador hasta Zacatena. Se trataba, por otra parte, del primitivo territorio sobre el que tenían jurisdicción las parroquias de Calatrava, ya delimitado en el transcurso de los primeros conflictos entre la Orden y los arzobispos de Toledo en la segunda mitad del siglo $x_{11}{ }^{21}$. Por el sur, pueden servir de referencia aproximada los actuales términos municipales de Carrión de Calatrava, hasta el núcleo poblacional ${ }^{22}$; mientras que por el norte su extensión debía también coincidir, en líneas generales, con el actual término municipal de Fernáncaballero, además del anejo de Peralvillo, hoy en día vinculado a la jurisdicción de

18 Publ. Eduardo de Hinojosa, Documentos para la historia de las instituciones de León y Castilla (siglos $x$-xilI), Madrid, 1919, págs. 148-150. El documento está fechado en 1230, pero Martín Rodríguez ocupó el maestrazgo entre 1237 y 1240. A principios del siglo XVI se seguía conservando la delimitación entre Miguelturra y el término de Calatrava la Vieja. Vid. AHN, OO. MM., carp. 463, n. 293 (se trata de una exención de pechos realizada por Fernando el Católico, en nombre de su hija doña Juana, a favor de los vecinos de Miguelturra, en abril de 1511).

19 Hinojosa, Documentos, pág. 149.

20 Sobre el tema vid. F. Ruiz Gomez, «La carta puebla de Ciudad Real (1255). Comentario histórico jurídico", Alfonso $X$ y Ciudad Real, Ciudad Real, 1986, 35-56; M. Santiago Yustres, "Génesis y desarrollo del alfoz de Ciudad Real (1255-1347)", I Congreso de Historia de CastillaLa Mancha. V. Musulmanes y cristianos: la implantación del feudalismo, Junta de Comunidades de Castilla-La Mancha, 1988, 173-185; y L.R. VILLEGAS DiAZ, Ciudad Real en la Edad Media (12551500), Ciudad Real, 1981; "De nuevo sobre la fundación de Cludad Real», Homenaje al Profesor Juan Torres Fontes, I, Murcia, 1985, 1779-1787; «Una gran villa e bona. Apostillas sobre la fundación de Ciudad Real», Alfonso X y Ciudad Real, Ciudad Real, 1986, 13-34; "Ciudad Real en la Edad Media", Historia de Ciudad Real. Espacio y tiempo de un núcleo urbano, Toledo, 1993, 73153; y "De Alarcos a Villa Real", Alarcos. El fiel de la balanza, (edición al cuidado de Juan Zozaya), Toledo, 1995, 61-80;

21 I.J. Ortega y Cotes, F. Álvarez de Baquedano, P. de Ortega Zúñiga y Aranda, Bullarium Ordinis Militiae de Calatrava, Madrid, 1761 (edición facsímil, Barcelona, 1981), pág. 20.

22 En el siglo xilı los términos de la aldea de Carrión debieron quedar constreñidos a una estrecha franja que se extendía entre el núcleo poblacional y el límite meridional del actual término municipal. 
Miguelturra. En la zona más oriental, tanto en progresión septentrional como meridional, los límites de Calatrava la Vieja incluirían buena parte del actual término municipal de Torralba, a excepción de la zona más meridional, ocupada ya por la propia aldea de Torralba, cuya parroquia se documenta desde mediados del siglo XIII ${ }^{23}$.

Una sentencia de Alfonso XI emitida en mayo de 1329, en el contexto del conflicto que enfrentó a la Orden de Calatrava con el concejo de Villa Real ${ }^{24}$, confirma, en cierta medida, la extensión de los términos de Calatrava la Vieja que acabamos de apuntar al situar como pertenecientes a la jurisdicción de la villa los lugares de El Turrillo ${ }^{25}$, Celada ${ }^{26}$, Peralvillo y Fernáncaballero, que debían ser devueltos a la Orden por el concejo de Villa Real ${ }^{27}$. Villegas interpreta que estos cuatro lugares pertenecían a la encomienda de Calatrava la Vieja, mientras que Fuente del Fresno y Robledo ${ }^{28}$ estaban vinculados a la encomienda de Malagón ${ }^{29}$. Es muy probable que la jurisdicción territorial de estas villas y las competencias de cada una de las encomiendas fueran coincidentes, pero lo cierto es que el documento de 1329 alude únicamente a la pertenencia de los mencionados lugares a Calatrava la Vieja y a Malagón, sin especificar si se trataba de las respectivas encomiendas.

Paralelamente al proceso de reducción del término de Calatrava la Vieja a lo largo del siglo xill, se crearon nuevos núcleos poblacionales en el interior de su territorio. El primero de ellos fue Fernáncaballero, fundado hacia

23 Archivo de la Catedral de Toledo, sign. O.7.D.1.75. y I.10.A.1.1.

24 Sobre el desarrollo de este conflicto durante los siglos medievales vid. J.C. BuITRAGo OLIVER, “Ciudad Real y Calatrava en el siglo xv: Una pluralidad conflictiva», Montesinos, 7-8 (1988), 20-25; J.M. SÁNCHEZ BENITO, “Nuevas observaciones sobre los conflictos entre Ciudad Real y la Orden de Calatrava: el papel de la Hermandad Vieja en los siglos XIV y XV", Revista de la Universidad Nacional de Educación a Distancia. Centro Asociado de Cuenca, Anexo 4 (19901991), 59-73; L.R. VILLEGAS DIAZ, «Algunos datos acerca de las luchas entre la Orden de Calatrava y el concejo de Villa Real en la primera mitad del siglo XIV», VII Centenario del Infante Don Fernando de la Cerda, Instituto de Estudios Manchegos, 1976, 179-190; Id., "Calatrava y Ciudad Real. Unas notas sobre las relaciones entre la ciudad y la Orden (siglos XIII-XV)", Cuadernos de Estudios Medievales, 8-9 (1983), 215-240.

25 Despoblado situado en el extremo occidental del término municipal de Carrión de Calatrava. Vid. Mapa Topográfico Nacional y Mapa Militar de España, Escala 1:50.000, Hoja 759; Cartografía Militar de España, Escala 1:10.000, Hoja 18-30-20.

26 Su localización se relaciona evidentemente con un molino del mismo nombre, situado en el cauce del Guadiana, entre la azuda del Emperador y el molino de la Torre. Vid. Mapa Topográfico Nacional y Mapa Militar de España, Escala 1:50.000, Hoja 759.

27 AHN, OO.MM., carp. 431, n. ${ }^{\circ} 222$.

28 Su localización se relaciona con el «Caserío El Robledo», situado al norte de Fuente del Fresno, en el extremo noroccidental del término municipal de Villarrubia de los Ojos. Vid. Mapa Topográfico Nacional, Escala 1:50.000, Hoja 737.

29 VILLEGAS, «Calatrava y Ciudad Real», pág. 227. 
$1218^{30}$, curiosamente coincidiendo con el traslado de la sede de la Orden a la fortaleza de Calatrava la Nueva. Su prosperidad se fundamentó en su estratégica situación en el camino de Toledo a Córdoba, a medio camino entre Malagón y la futura Villa Real. La decadencia de Calatrava la Vieja fue beneficiosa para su desarrollo inicial, como ocurrió con el resto de las poblaciones de esa zona del Campo de Calatrava. A Fernáncaballero se unirían en el transcurso del siglo XIII, El Turrillo, La Celada y Peralvillo.

En cualquier caso, interesa subrayar que desde finales del siglo XIII, debido a la configuración del alfoz de otras poblaciones limítrofes, la tierra de Calatrava la Vieja quedó constreñida a los términos que hemos señalado. En los siglos venideros, los principales bienes y rentas de la encomienda de Calatrava la Vieja estarían fuera de los estrechos términos de la villa.

Durante la primera mitad del siglo XIV, Ilama poderosamente la atención que buena parte de la documentación que conservamos sobre la zona central del Campo de Calatrava se refiera a molinos situados en el cauce del Guadiana ${ }^{31}$. Así, por ejemplo, en la mencionada sentencia de Alfonso XI de 1329, el monarca castellano ordena al concejo de Villa Real que entregue a la Orden de Calatrava los molinos de El Espino, Gajión, Gaitán, Nuevo, Pedro Sancho, Batanejo, El Emperador, La Celada y Torre Merina. El orden de relación de los molinos en el documento sigue una dirección geográfica desde la parte más occidental a la más oriental. De todos ellos, los tres últimos se situaban en término de Calatrava la Vieja. Tal vez pudo estar relacionado de algún modo con esta última el molino de Batanejo, el más próximo de los restantes, a pesar de su situación en término de Villa Real. De los demás molinos, sabemos que el de Gajión era propiedad del maestre calatravo Garci López de Padilla, según un documento de $1316{ }^{32}$. Este dato nos induce a pensar que este molino pudo estar vinculado con la mesa maestral.

Por otra parte, y en relación con los molinos que pudieron estar relacionados económicamente con Calatrava la Vieja, existe en estas primeras décadas del siglo XIV cierta tendencia a cederlos vitaliciamente. Ya vimos el caso de la azuda de El Emperador para el siglo XIII. Ahora, en el siglo XIV, los receptores principales de esas cesiones vitalicias son fundamentalmente

30 VIÑAS Y PAZ, Relaciones, pág. 273.

31 Un estudio sobre esta cuestión en Enrique Rodríguez-PICAVEA MATILLA, «La difusión del molino hidráulico en el Campo de Calatrava (siglos Xli-XIV)", en Ricardo IzQUIERDO BENITO y Francisco RuIz Gómez (Coordinadores), Actas del Congreso Internacional Conmemorativo del VIII Centenario de la Batalla de Alarcos (1995. Ciudad Real), Cuenca, 1996, págs. 533-554.

32 AHN, OO.MM., sign. 1345c, fol. 136. 
judíos. Así, en mayo de 1310, don Zulema ben Albagal y su mujer doña Jamila, judíos y moradores en Villa Real, tenían cedidas por parte de la Orden de Calatrava las aceñas de «pan moler» del Batanejo. En esa fecha vendieron sus derechos en estas explotaciones a Alfonso Fernández Tercero y Fernando Pérez, vecinos de Miguelturra, por 15.000 maravedís y la condición de dejarlas posteriormente a la Orden de Calatrava ${ }^{33}$. Un lustro después, el maestre Garci López de Padilla cedió vitaliciamente las aceñas de La Celada a Abrahem aben Zazón, judío y vecino de Villa Real ${ }^{34}$. Estas mismas aceñas, junto con el castillo de Canena y los molinos de Pedro Sancho, también sobre el Guadiana, habían sido cedidas por el citado maestre calatravo al almojarife real don Samuel Abrananiel ${ }^{35}$, a cambio de las condonación de las deudas que con él tenía pendientes y la condición de que fueran convenientemente reparadas.

Al margen de estos datos, lo más sobresaliente en la evolución de la villa y la encomienda durante el siglo XIV es la ausencia de Calatrava la Vieja de la documentación que ha llegado hasta nosotros. Un silencio extraordinariamente significativo, que nos indica claramente que esta centuria marca la definitiva decadencia del núcleo poblacional de Calatrava la Vieja. El silencio documental se romperá a finales del siglo XIV, pero sólo para indicarnos el nombre de dos comendadores de Calatrava la Vieja: Rodrigo Chamizo, que ocupó el cargo durante el maestrazgo de Pedro Muñíz de Godoy (1369-1384) ${ }^{36}$, y Juan García, que asistió al Capítulo General de la Orden celebrado en 1397 en el convento de Calatrava la Nueva ${ }^{37}$. Precisamente, en esta importante reunión se decidió la fundación de varios prioratos, además de la confirmación de los ya existentes, para ofrecer servicios religiosos a los freires de la Orden en cada comarca. En total se aprobó la existencia de catorce prioratos. Entre ellos, se fundó en Calatrava la Vieja el priorato de Santa María de los Mártires. Los

33 AHN, OO.MM., carp. 462, n. ${ }^{\circ}$ 193; ibid., sign. 1345c, fol. 72. Publ. Antonio Benavides, Memorias de d. Fernando IV de Castilla, 2 vols., Madrid, 1860, II, págs. 745-746.

34 AHN, OO.MM., carp. 463, n. ${ }^{\circ} 200 ;$ ibid., sign. 1345c, fol. 119.

35 Probablemente se trata del almojarife don Samuel, judío natural de Andalucía, que ocupó el cargo durante el reinado de Fernando IV. Este dato coincide cronológicamente con el maestrazgo de Garci López de Padilla (1296-1329). El almojarife don Samuel gozaba de la confianza del monarca castellano, pero era odiado por la población y se granjeó la oposición de los partidarios de María de Molina. Su muerte tuvo lugar en 1306, en el transcurso de un viaje a Aragón (vid. Yitzhak BAER, Historia de los judíos en la España cristiana, 2 vols., Madrid, 1981, I, pág. 241). En consecuencia, el documento cabe fecharlo en la década que transcurre entre 1296 y 1306 . En este sentido, apuntamos como fecha más probable la de 1303, explicable por el error del copista que fechó el documento en 1353, introduciendo la cifra «L». Vid. AHN, OO.MM., sign. 1347c, fol. 134.

36 Rades, Chronica de Calatrava, fol. $62 \mathrm{r}$.

37 ORTEga y Cotes, Bullarium, pág. 225. 
cuatro restantes situados en el Campo de Calatrava eran los de Zuqueca -en término de Almagro-, Fuencaliente, Mochuelos -en término de Almodóvar-y Ureña-en término de Daimiel ${ }^{38}$, además del priorato del Sacro Convento de Calatrava. Todos ellos, por tanto, situados al sur de Calatrava la Vieja, por lo que es posible que el priorato de Santa María de los Mártires se encargara de atender las necesidades religiosas - misas, confesiones, comuniones y entierros - de los freires calatravos que vivían en la zona septentrional del Campo de Calatrava.

\section{LA CONSOLIDACIÓN DE LA ENCOMIENDA DE CALATRAVA LA VIEJA Y LA DESPOBLACIÓN DEFINITIVA DE LA VILLA}

En el transcurso de las primeras décadas del siglo $x v$ la sede de la encomienda de Calatrava la Vieja se trasladó a El Turrillo ${ }^{39}$. Parece que el traslado ya se había consumado en 1418 , cuando contamos con la referencia de la primera visita realizada a la encomienda. Cinco años después, en febrero de 1423, en el lugar se habian realizado nuevas construcciones, adecuadas a la función que a partir de ese momento desempeñará El Turrillo. Entre las obras realizadas destaca la construcción de una torre, emprendida por el propio comendador Manuel Gonzalo ${ }^{40}$. Tales obras pueden interpretarse como el indicio del traslado de la sede de la encomienda desde Calatrava la Vieja hasta El Turrillo.

Además de las casas de El Turrillo, destacan en 1423 como propiedad de la encomienda los molinos de La Celada, que se encontraron también en muy buen estado. Todo ello llevó a que los visitadores calificaran al comendador Manuel Gonzalo como un «buen granjero, buen comendador, buen administrador y buen distribuidor» ${ }^{41}$.

Por su parte, después del traslado de sede, la antigua población de Calatrava la Vieja quedó convertida en dehesa. Tal vez permanecieron en ella algunos individuos encargados de su cuidado y explotación, pero el núcleo poblacional languideció irremediablemente.

A lo largo del siglo xv la sede de la encomienda de Calatrava la Vieja se mantuvo en las casas situadas en El Turrillo. Durante este período

RADES, Chronica de Calatrava, fol. 64r.

Sobre la evolución posterior de esta explotación vid. Eduardo RODRíGUEZ ESPINOSA, «El Turrillo (Carrión de Cva.): un tipo de explotación agraria en régimen semicomuna|», Cuadernos de Estudios Manchegos, 17 (1987), 125-136.

40 AHN, OO.MM., sign. 1412C, fol. 30r-31r

41 Ibid. 
conocemos los nombres de algunos freires que ostentaron el título de comendador de Calatrava la Vieja: Fernando de Córdoba, presente en la elección del maestre Pedro Girón en $1445^{42}$; Gonzalo de Lucio, que ocupó el cargo durante la primera parte del maestrazgo de Rodrigo Téllez Girón (1466-1482) ${ }^{43}$, siendo además gobernador del Campo de Calatrava ${ }^{44}$; Pedro Benegas, que figura en un documento de $1477^{45} \mathrm{y}$ en calidad de representante de la Orden en el acuerdo firmado con el arzobispo de Toledo en enero de $1482{ }^{46}$; y Sancho de Sotomayor, que era comendador en la visita efectuada en marzo de $1493^{47}$.

A través de las visitas realizadas durante el último tercio del siglo $x v$ y primeros años del siglo XVI tenemos constancia de los bienes y rentas pertenecientes a la encomienda durante este período ${ }^{48}$. Además de las mencionadas casas de El Turrillo, que constituían la residencia del comendador, destacaban las dehesas de Calatrava - donde estaba la antigua villa y fortaleza, núcleo originario de la Orden-, El Turrillo y La Celada, además de las sernas de El Turrillo, una bodega en este mismo lugar, con cinco cubas y 23 tinajas, el molino situado en la dehesa boyal —en el arroyo de Bañuelo, dentro del término de Fernáncaballero- $y$, por último, el río Guadiana a lo largo de los términos de Calatrava la Vieja, con la pesca correspondiente.

A estas propiedades es necesario agregar las rentas pertenecientes a la encomienda, entre las que se encontraban las siguientes:

- El diezmo de las viñas que los vecinos de Carrión y Villa Real tenían en término de El Turrillo, valorado anualmente en 600 arrobas de vino.

- El diezmo del pan de la dehesa de El Turrillo.

- El diezmo de los colmenares, piñas y pinos que estaban en el término de Fernáncaballero.

- El diezmo de los corderos, la lana, mozos, potricos, becerros y otras menudencias.

42 Rades, Chronica de Calatrava, fol. 78r.

43 Aparece como tal en la visita de 1471. Vid. AHN, OO.MM., leg. 6.075, n. ${ }^{\circ}$, fols. $71 \mathrm{v}-73 \mathrm{r}$.

44 RADES, Chronica de Calatrava, fol. $81 \mathrm{v}$.

45 AHN, OO.MM., leg. 6.110, n. 23 , tol. 86.

46 ORTEga y COTES, Bullarium, pág. 279.

47 AHN, OO.MM., leg. 6.109, fol. 174-177.

48 Los datos que reseñamos a continuación proceden de las visitas realizadas a la encomienda de Calatrava la Vieja en $1471,1493,1502$ y 1510 . Vid. AHN, OO.MM., leg. 6.075, n. ${ }^{\circ} 1$, fol. $71 v-72 v$ : leg. 6.109, n. $^{\circ} 22$, fol. $174-179$; leg. 6.110, n. $^{\circ} 2$, fol. $54-56$, y n. ${ }^{\circ} 23$, fol. 82-88. Estos datos fueron recopilados también en la tesis doctoral de Emma SOLANO, La Orden de Calatrava en el siglo XV. Los señoríos castellanos de la Orden al fin de la Edad Media, Universidad de Sevilla, 1978, págs. 199-201 y 407-408. 
- El diezmo de pollos, ansarones y lechones de Carrión. Celadilla.

- El pie de altar y las minucias de Carrión.

- La mitad del pie de altar de Fernáncaballero y de las dehesas y términos de Calatrava y El Turrillo.

- "Penas y caloñas" de las dehesas y términos de Calatrava, El Turrillo, Fernáncaballero y Carrión. Además de estos derechos judiciales, se reseñan también los derivados de los bienes mostrencos de Carrión y Fernáncaballero y el tablero o «pena de los juegos de dados y naipes» de este último lugar.

- La montaracía de Fernáncaballero.

- Un yantar en Carrión por valor de 80 maravedís y otro en Fernáncaballero por valor de 100 maravedís.

- Cada vecino de Fernáncaballero debía entregar a la encomienda una gallina.

- Un real por cada "res de monte» capturada en Fernáncaballero.

- La renta de los «pozos del barro» de los vecinos de Villa Real.

- La renta del esparto, obtenida de la venta de la hebra y valorada en 1471 en 2.000 maravedís.

Finalmente, a todos estos derechos habría que unir las rentas derivadas del arrendamiento de algunas propiedades. Así, por ejemplo, la dehesa de Calatrava fue arrendada en invierno y en verano por un total de 53.500 maravedís en 1471. En 1509 la misma dehesa se arrendó por 93.000 maravedís. En 1471 la dehesa de El Turrillo con La Celadilla fue arrendada -también para invierno y verano- - por 25.000 maravedís y una parte del diezmo. En marzo de 1477, el comendador de Calatrava la Vieja, Pedro Benegas, cedió a censo a Alfonso Martínez, vecino de Fernáncaballero, el molino que tenía en el arroyo Bañuelo a cambio de que le entregara anualmente dos pares de gallinas buenas y la condición de que construyera uno, dos o los rodeznos que fuera posible en el molino. Al parecer el censo seguía vigente en 1510, ya que entonces se sacó un traslado del documento original ${ }^{49}$.

Por lo que se refiere al valor global de la encomienda, en la primera de las visitas, la de 1471, la encomienda de Calatrava la Vieja fue valorada

49 AHN, OO.MM., leg. 6.110, n. ${ }^{\circ} 23$, fol. 86. 
en 82.600 maravedís. Más de una veintena de años después (1493), la valoración global de la encomienda había ascendido a 124.875 maravedís y al comendador le correspondía aportar cinco lanzas. En 1500 su valor descendió a 109.865 maravedís. En la década siguiente superó todas las cifras anteriores para situarse en una equivalencia monetaria de 130.010 maravedís, además de 30 gallinas y doce arreldes ${ }^{50}$ de peces, pero la aportación de lanzas había descendido hasta tres. Teniendo en cuenta estos datos y comparándolos con los de otras encomiendas calatravas durante el mismo ámbito cronológico, Emma Solano ha situado a Calatrava la Vieja como una encomienda de tipo medio, con una rentabilidad bastante elevada ${ }^{51}$.

En las dos últimas décadas del siglo xv las casas de El Turrillo, sede de la encomienda de Calatrava la Vieja, entraron en un proceso de creciente deterioro. En la visita realizada en marzo de 1493 por Juan de Almagro, sacristán del convento de Calatrava, y Pedro de Aguayo, comendador de Bívoras, se encontraron las casas derruidas y el comendador Sancho de Sotomayor estaba ausente, ya que no vivía en ellas. Los visitadores ordenaron al comendador de Calatrava la Vieja que reparara todos los edificios y que fuera a residir en ellos o, en caso contrario, mandara hacerlo a una persona en representación suya ${ }^{52}$. Sin embargo, la medida no surtió efecto y en una nueva visita realizada en febrero de 1502, ante el abandono y el deterioro de las casas de El Turrillo, los visitadores ordenaron al nuevo comendador de Calatrava la Vieja Pedro Vélez de Jaén que trasladara la sede de la encomienda a la villa de Carrión, tal y como se había acordado en el Capítulo General de la Orden. Para ello el comendador debia edificar o comprar unas casas acordes con la dignidad de su cargo para que él y sus servidores pudieran residir en ellas ${ }^{53}$. Ocho años después, cuando se efectuó la siguiente visita, los nuevos visitadores comprobaron que ya se habían comprado las nuevas casas en la villa de Carrión, cerca de la iglesia, y se estaban realizando las obras necesarias para acondicionarlas como residencia del comendador Pedro Vélez de Jaén. Además, en el período comprendido entre 1502 y 1510, el propio comendador había acrecentando las propiedades de la encomienda en la villa de Carrión con la compra de dos quiñones de tierra para cereal y varias viñas con un total 9.100 vides ${ }^{54}$.

\footnotetext{
El arrelde equivalía en Castilla a cuatro libras de peso.

Solano, La Orden de Calatrava, pág. 201.

AHN, OO.MM., leg. 6.109, n. ${ }^{\circ} 22$, fol. 174-177.

AHN, OO.MM., leg. 6.110, n. ${ }^{\circ} 2$, fol. 54-56.

AHN, OO.MM., leg. 6.110, n. ${ }^{\circ} 23$, fol. 82-84.
} 
En consecuencia, desde principios del siglo xvI, la sede de la encomienda de Calatrava la Vieja se trasladó de El Turrillo a la villa de Carrión, donde se mantendría en los siglos venideros. Para entonces las dos poblaciones de la encomienda eran la propia Carrión, que contaba aproximadamente con 130 vecinos ${ }^{55}$, y Fernáncaballero, que acogía una población de unos 30 vecinos ${ }^{56}$. La encomienda siguió conservando durante buena parte del siglo xvı el título de Calatrava la Vieja -aunque con la aclaración entre paréntesis de que se trataba también de la encomienda de Carrión ${ }^{57}$-, pero la villa que daba nombre a la encomienda ya no volvería a poblarse, prevaleciendo su valor como dehesa. Hacia 1520, cuando Hernando de Colón pasó por la antigua sede de la Orden de Calatrava encontró el lugar completamente despoblado, aunque todavía quedaban en pie las casas muy fuertes de tierra, e tiene aun fortaleza, e están en pie los palacios del rrey moro ${ }^{58}$. En 1526, otro ilustre viajero, Andrés Navagero, transmite la imagen de ruina y abandono de la otrora floreciente ciudad ${ }^{59}$. Medio siglo después, cuando se redactaron las Relaciones de Felipe II, se consignó la existencia de la ermita de Nuestra Señora la Blanca, en el interior de la fortaleza, que esta fuerte y bien reparada, y la ermita de Nuestra Señora de los Mártires, antigua sede del priorato, que conservaba también el muro fuerte ${ }^{60}$.

A partir del último cuarto del siglo XVi la encomienda pasó a denominarse encomienda de Carrión. Los restos materiales de la villa y fortaleza de Calatrava la Vieja continuaron su existencia formando parte de la dehesa del mismo nombre ${ }^{61}$, propiedad de la encomienda de Carrión. En ella todavía en el siglo XVIII se criaban yeguas y mulas ${ }^{62}$, y en el siglo XIX se arrendaban sus pastos para ovejas y yeguas ${ }^{63}$.

55 Hernando de Colón, Descripción y cosmografía de España. Manuscrito de la Biblioteca Colombina, 3 vols., Madrid, 1910-1917, 1, pág. 333.

56 AHN, OO.MM., leg. 6.110, n. ${ }^{\circ} 23$, fol. $88 \mathrm{r}$.

57 Corchado, El Campo de Calatrava, II, pág. 196.

58 Hernando de Colón, Descripción y cosmografia, I, pág. 264

59 Andrés Navagero, Viaje por España (1524-1526), edición de Antonio María Fabié, Madrid, 1983, pág. 69

60 VIÑAS y PAZ, Relaciones, págs. 186 y 188.

61 El valor de la dehesa de Calatrava en relación con el conjunto de las dehesas del Campo de Calatrava en el siglo xVI puede comprobarse en Jerónimo López-SALAZAR PÉREZ, Mesta, pastos y conflictos en el Campo de Calatrava durante el siglo XVI, Madrid, 1987, págs. 9-36.

62 Documento de 1753, cuando era comendador de Carrión el duque de Híjar. Vid. AHN, OO.MM., Archivo Judicial de Toledo, leg. 47.623, 47.624 y 47.625.

63 La evolución de la encomienda de Carrión entre los siglos XV1 y XIX puede encontrarse en CoRChado, El Campo de Calatrava, II, págs. 196-205. 


\section{ACTIVIDADES ECONÓMICAS}

Entre las actividades económicas ${ }^{64}$ desarrolladas en Calatrava la Vieja ocupaba un lugar destacado la agricultura ${ }^{65}$. Los cultivos principales eran los cereales, integrados por el gran binomio que componían trigo y cebada, orientados básicamente hacia la alimentación humana para la elaboración de pan. La cebada, especialmente cuando estaba plantada en alcaceres, se destinaba a la alimentación del ganado. En menor medida se plantaba centeno. Las proporciones en las que aparecen estos cereales en la documentación varían, pero siempre destaca la preponderancia del trigo y la cebada. En diciembre de 1257, doña Inés arrendó a Gonzalo Ruiz una heredad de cuatro yugadas en el mismo lugar. La parte sembrada comprendía cinco cahíces y medio de cebada, 22 fanegas de trigo, tres fanegas de centeno y dos fanegas de alcacer ${ }^{66}$. Esta preponderancia del cereal entre los cultivos de la zona se mantuvo a lo largo de toda la Edad Media y se constata todavía en el siglo XVI ${ }^{67}$.

A los cereales, les seguían en importancia los viñedos. Después de 1212, cuando se inició una tarea de colonización de la comarca mucho más intensa, la Orden de Calatrava incentivó la plantación de viñedos en una zona limítrofe con la que estamos estudiando como era la del término de Miguelturra. En eí fuero otorgado a esta aldea del Campo de Calatrava a finales de la década de 1230 el maestre Martín Rodríguez dispuso que el cavallero de Miguel Turra a de poner dos aranzadas de viña e el peon una aranzada. E todo cavallero o peon que fasta un año no lo tubiere puesto, que pierda la heredad, e el Comendador de la posesion dello con consexo de los hombres buenos del lugar ${ }^{68}$. Es decir, se fomentaba efectivamente la plantación de viñas, amenazando en caso contrario con la pérdida de la heredad si en el plazo de un año tanto caballeros como peones no habían plantado la extensión de viñedo que les correspondía.

\footnotetext{
${ }_{64}$ Recientemente se ha apuntado como posibilidad que en los primeros tiempos los señoríos calatravos fueran explotados según el modelo económico cisterciense. Vid. Luisa NAVARRO DE LA TORRE, «El modelo económico cisterciense y la Orden de Calatrava. Siglos XII-XIII», en Ricardo IzQUiERdo Benito y Francisco Ruiz Gómez (Coordinadores), Actas del Congreso Internacional conmemorativo del VIII centenario de la Batalla de Alarcos, Cuenca, 1996, 459-469. Sin embargo, los datos manejados sobre Calatrava la Vieja nada nos permiten aportar a esta sugerente hipótesis.

65 Un interesante estudio sobre la organización del paisaje rural en una zona próxima a Calatrava la Vieja puede encontrarse en L.R. VILLEGAS DIAZ, «Propiedad y paisaje agrario en el Campo de Calatrava a fines de la Edad Media», Cuadernos de Estudios Medievales, 18 (1988), 57-115.

66 Archivo de la Catedral de Toledo, sign. A.11.F.1.2.

67 SOLANO, La Orden de Calatrava, pág. 200.

68 Publ. HINOJOSA, Documentos, pág. 150.
} 
En consecuencia, a lo largo del siglo XIII, podemos hablar de un crecimiento del viñedo en algunas zonas del Campo de Calatrava. En parte este crecimiento fue fomentado y estuvo canalizado por la Orden de Calatrava, ya que el cultivo de la uva, utilizado básicamente para su transformación en vino, estaba orientado fundamentalmente a la comercialización. Se trataba de un cultivo bastante estable, dada su regularidad anual y su fácil conversión en renta ${ }^{69}$. En contrapartida, el cultivo de las viñas necesitaba una mayor especialización y mayores cuidados y atenciones. En diciembre de 1257, doña Inés arrendó a Gonzalo Ruiz, de Villa Real, cinco aranzadas y media de viñas, además de otros bienes, todos ellos situados en Calatrava la Vieja y su término. El arrendamiento se realizaba por un período de cuatro años a cambio de 500 maravedís alfonsinos. En relación a las viñas se establecía como condición ineludible la obligación de realizar cuatro labores anuales: excavar, podar, binar y cavar. Si en el plazo de cuatro años las viñas sufrían algún perjuicio como consecuencia de no haber realizado las cuatro labores mencionadas, Gonzalo Ruiz se comprometía a pagar el daño ocasionado a doña Inés ${ }^{70}$.

En el siglo $x V$, una parte de las rentas de la encomienda de Calatrava la Vieja procedía de las viñas. En 1471, por ejemplo, el diezmo de las viñas que tenían en el término de El Turrillo los vecinos de Villa Real y Carrión proporcionaba anualmente a la encomienda 600 arrobas de vino. En esa misma fecha, se da cuenta de que en la bodega situada en las casas de El Turrillo, y perteneciente a la encomienda, había cinco cubas y 23 tinajas compradas por el comendador ${ }^{71}$. En 1493 se reseñan dieciocho tinajas y siete cubas, pero ya en estado de deterioro ${ }^{72}$. Por esta causa y el traslado de la sede de la encomienda a Carrión, el comendador de Calatrava la Vieja Pedro Vélez de Jaén compró en aquella villa, durante la primera década del siglo XVI, siete viñas: un majuelo de 1.200 vides, una viña de 400 , tres de 1.000 , una de 1.500 y otra de 3.000 . Un total de 9.100 vides que pasaron a pertenecer a la encomienda calatrava ${ }^{73}$. La extensión de viñedo calatravo en Carrión equivalía a unas dieciocho aranzadas de viña, siguiendo la proporción de 500 vides por cada aranzada ${ }^{74}$.

\footnotetext{
69 Sobre esta cuestión vid. Miquel BARCELÓ, «La arqueología extensiva y el estudio de la creación del espacio rural», en M. BARCELó y otros, Arqueología medieval. En las afueras del «medievalismo», Barcelona, 1988, págs. 203-208.

70 Archivo de la Catedral de Toledo, sign. A.11.F.1.2.

AHN, OO.MM., leg. 6.075, n. ${ }^{\circ} 1$, fol. $72 \mathrm{v}$.

AHN, OO.MM., leg. 6.109, $n{ }^{\circ} 22$, fol. $174 \mathrm{v}$.

73 AHN, OO.MM., leg. 6.110, n. ${ }^{\circ} 23$, fol. 82v.

${ }^{74}$ Esta proporción figura en la Relación de Carrión. Vid. Viñas y PAZ, Relaciones, pág. 186.
} 
Por encima de la agricultura, la actividad económica fundamental en Calatrava la Vieja y su término fue la ganadería. A partir del siglo xIII, y especialmente en los siglos XIV y XV, el proceso de despoblamiento experimentado por Calatrava la Vieja no sólo no impidió el desarrollo pecuario sino que propició la conversión de los antiguos núcleos poblacionales en dehesas ganaderas. Esto fue lo que ocurrió con la propia villa fundacional de la Orden y con El Turrillo. En el siglo XV ambas dehesas formaban parte de la encomienda de Calatrava la Vieja, constituyendo también sus propiedades más rentables, ya que en 1471 fueron arrendadas como pasto de invierno y verano en 53.500 y 25.000 maravedís respectivamente ${ }^{75}$. Junto al arrendamiento de las dehesas de Calatrava la Vieja y El Turrillo, la parte más importante de las rentas de la encomienda era la que procedía del diezmo de los corderos (13.600 maravedis), la lana ( 14.530 maravedís) y de los mozos, potras, bezerros e otras menudençias (6.000 maravedís) ${ }^{76}$. Con todos estos datos se demuestra fehacientemente que la explotación ganadera era la actividad económica principal en la estructura de la encomienda de Calatrava la Vieja.

Según las Relaciones de Felipe II, cuyos datos pueden marcar una tendencia anterior, las cabañas más abundantes en la zona de Calatrava la Vieja eran la ovina y la cabría. Menos importancia tenían los caballos, bueyes, vacas, burros y cerdos ${ }^{77}$. A todas estas especies habría que añadir las aves de corral, especialmente las gallinas, utilizadas en el siglo XV como unidad para el pago de diversas rentas a la encomienda de Calatrava la Vieja. Indudablemente esto indica que la gallina era un animal presente en casi todos los hogares.

Además de pasto, los montes y baldíos, sobre todo los situados al norte de Calatrava la Vieja, encerraban una riqueza natural muy notable, lo que permitía la práctica de actividades económicas complementarias y muy necesarias para una economía que dependía en exceso del medio físico. En el ámbito de influencia de la villa y la encomienda de Calatrava la Vieja la zona más abundante en leña era la de Fernáncaballero: es tierra abundosa de leña menuda, jarales y laviernagos y lantiscos y romero y coxcoxa y poco monte pardo y baxo ${ }^{78}$. En el término de dicha villa había también pinos. Precisamente el diezmo de sus piñas pertenecía a finales

75 AHN, OO.MM., leg. 6.075, n. ${ }^{\circ}$, fol. $71 \mathrm{v}-72 \mathrm{v}$.

76 En esas cantidades fueron evaluadas estas rentas en 1509. Vid. AHN, OO.MM., leg. 6.110, n. ${ }^{\circ} 23$, fol. $88 \mathrm{r}$.

77 Viñas y PaZ, Relaciones, págs. 186 y 275.

78 Ibid., pág. 274. 
del siglo $\mathrm{XV}$ a la encomienda de Calatrava la Vieja ${ }^{79}$. La montaracía de Fernáncaballero podía ser arrendada para hacer carbón ${ }^{80} \mathrm{Al}$ sur de Calatrava la Vieja, en el término de Carrión, se documenta desde la primera mitad del siglo XIII la existencia de un encinar, que constituía una dehesa limítrofe con el concejo de Miguelturra ${ }^{81}$.

Relacionada con la explotación del bosque se encuentra la práctica de la apicultura, que conoció gran desarrollo en toda Castilla la Nueva debido a la escasez de aceite y azúcar ${ }^{82}$. Las abejas podían proporcionar la cera para el alumbrado cotidiano y la miel para endulzar los alimentos. En Fernáncaballero, en la misma zona de los pinares, conocemos la existencia de colmenares. Naturalmente, la práctica de la apicultura no podía quedar al margen del control señorial de la Orden de Calatrava: a finales del siglo xv la encomienda de Calatrava la Vieja contaba entre sus rentas con el diezmo de los mencionados colmenares del término de Fernáncaballero ${ }^{83}$.

Montes y bosques eran también el lugar propicio para el desarrollo de la caza. En consecuencia resulta lógico que fuera también Fernáncaballero la zona más adecuada para la práctica cinegética. Probablemente era la única zona en el ámbito de la encomienda de Calatrava la Vieja donde se podía practicar la caza mayor. Sin embargo, por cada res de monte capturada en Fernancaballero la encomienda de Calatrava la Vieja percibía un real ${ }^{84}$.

Por el contrario, al sur del Guadiana sólo encontramos caza menor: no hay sino liebres estas pocas y algunas perdices que se halla pocas veces, hay algunos lobos y zorras y estos lobos se crian en el rio Guadiana por tener muchas fustas hulares, masegares $y$ carrizales $y$ ir muy ancho por este termino ${ }^{85}$.

Además, el cauce del Guadiana permitía que la pesca fuera una actividad relativamente frecuente. Se pescaba en barca o a pie, utilizando el anzuelo, la red o la nasa. En el Guadiana, a su paso por el término de Calatrava la Vieja, las especies y los sistemas de pesca no debían ser muy diferentes a los descritos en el siglo XVI: Los pescados que se toman

\footnotetext{
AHN, OO.MM., leg. 6.109, n. ${ }^{\circ} 22$, fol. 175 r.

AHN, OO.MM., leg. 6.110, n. ${ }^{\circ} 23$, fol. $82 \mathrm{v}$.

HINOJOSA, Documentos, pág. 149.

Julio GonzÁlez, Repoblación de Castilla la Nueva, 2 vols., Madrid, 1975-76, II, págs. 351-353.

AHN, OO.MM., leg. 6.109, n. ${ }^{\circ} 22$, fol. 175 r.

AHN, OO.MM., leg. 6.110, n. ${ }^{\circ} 23$, fol.82v.

VIÑAS y PAZ, Relaciones, pág. 184.
} 
y se pescan en el dicho rio Guadiana con redes de hilo y con delitos de juncos son peces, los mayores de libra poco mas o menos y los menores como lampreas, pescase tambien lampreas y camarones, ansarhitos y hornachos son como el dedo de largo, las lampreas es buen pescado y los camarones son menuditos de manera de grillos, es buen pescado, tomanse y pescanse grillos que las mayores de ellas seran de seis a ocho libras, tienense por muy excelentes pescados ${ }^{86}$. Río arriba, en la zona correspondiente al término de Torralba, los pescados más apreciados eran las anguilas - de una vara de largo y casi una cuarta de ancho- y las lampreas, además de algunos barbos y abundantes bogas ${ }^{87}$ y cachuelos ${ }^{88}$, aunque estas dos últimas especies tenían menor valor ${ }^{89}$. Los datos que ofrece la documentación coinciden esencialmente con el análisis de la ictiofauna, realizado a partir de los huesos extraídos de la excavación del yacimiento almohade de Calatrava la Vieja ${ }^{90}$.

A finales del siglo XV, los derechos de pesca en el Guadiana, a lo largo del término de Calatrava la Vieja, pertenecían al comendador de este lugar. En 1509 la pesca en el Guadiana rentó a la encomienda 2.700 maravedís y doce arreldes de peces ${ }^{91}$. Posteriormente se produjo una distinción entre lo que se pescaba con barco, que debía pagar los derechos al comendador correspondiente, y la «pesca a peón», que pertenecía enteramente a los vecinos de la villa de Carrión ${ }^{92}$.

Otro sector económico importante era el integrado por todas aquellas actividades relacionadas con la transformación de las materias primas. En este sentido resultaba fundamental la infraestructura tecnológica proporcionada por los molinos hidráulicos. Desde principios del siglo XIV —probablemente ya presentes antes de 1300- conocemos la existencia de las

\footnotetext{
86 VIÑAS y PAZ, Relaciones, págs. 184-185.

87 «Pez teleósteo, fisóstomo, que puede alcanzar 40 centímetros de largo, aunque comúnmente es menor, de color plateado y con aletas casi blancas. Abunda en los ríos españoles y es comestible». Vid. Diccionario de la lengua española. Real Academia Española, vigésima primera edición, Madrid, 1992, voz boga.

88 «Pez teleósteo, fisóstomo, abundante en los ríos de la mitad meridional de España, de unos ocho centímetros de largo, de color azulado por el lomo y blanco amarillento por el vientre, con dos barbillas en los extremos de la boca, aletas pintadas de puntos pardos y cola ahorquillada. Su carne es fina y apreciada". Vid. Ibid., voz cachuelo.

89 Soledad LóPEZ FERNÁNDEZ, «Relaciones geográfico histórico estadísticas de los pueblos de España, mandada hacer por el rey d. Felipe Il», Cuadernos de Estudios Manchegos, 17 (1987), pág. 319.

90 Eufrasia Roselló IzQuierdo y Arturo MuñIz Morales, «Calatrava la Vieja: primer informe sobre la fauna de vertebrados recuperados en el yacimiento almohade. Tercera parte: peces», Boletín de Arqueología Medieval, 5 (1991), 113-133.

91 AHN, OO.MM., leg. 6.110, n. ${ }^{\circ} 23$, fol. $88 \mathrm{r}$.

92 VIÑAS y PAZ, Relaciones, pág. 185.
} 
aceñas de Batanejo, La Celada y Torre Merina. Para el siglo xV tenemos constancia de un molino en el arroyo de Bañuelo, dentro del término de Fernáncaballero. En el siglo XVI la relación de molinos se completa con los de Mal Vecino y Flor de Ribera. En definitiva, no menos de un decena de molinos que podemos poner en relación con Calatrava la Vieja y su término, desde el siglo xII hasta el xvi; todos ellos, a excepción del de Bañuelo, situados en el cauce del Guadiana.

Conviene reseñar que los molinos hidráulicos no constituían monopolios señoriales jurídicamente sancionados, pero también es verdad que ninguno escapaba al control señorial de la Orden de Calatrava. Otra cuestión es que la mayor parte de ellos fueran cedidos ocasionalmente por los calatravos a diversos particulares, a través de diferentes mecanismos de transferencia temporal: la donación vitalicia, el arrendamiento o la cesión a censo.

Frente a la presencia de molinos en la documentación relacionada con Calatrava la Vieja, destaca la escasa relevancia de los hornos en los testimonios escritos que han llegado hasta nosotros. El único horno que tenemos documentado es el que estaba en las casas de El Turrillo. Aparece por primera vez en febrero de 1423, cuando el lugar probablemente ya era la sede de la encomienda de Calatrava la Vieja ${ }^{93}$. Casi medio siglo después, en 1471, todavía se constata su presencia en El Turrillo ${ }^{94}$, pero en 1493 la casa del horno ya estaba cayda e descubierta ${ }^{95}$. Sin embargo, resulta evidente que los hornos son imprescindibles para finalizar el proceso de transformación del cereal en pan que se inicia con la trituración del grano en los molinos. En este sentido, puede ser muy significativo el fuero de Miguelturra, una aldea limitrofe con Calatrava la Vieja y estrechamente relacionada con toda la zona. En este ordenamiento foral se sanciona el monopolio de la Orden de Calatrava sobre el horno del lugar ${ }^{96}$. El silencio documental sobre estos instrumentos de transformación de las materias primas podría indicar el monopolio calatravo de los mismos y el deseo de la Orden de no desprenderse, ni siquiera a través de cesiones vitalicias, de los hornos.

Esto mismo parece ocurrir con otro lugar de transformación de materias primas como era el lagar de! vino. También aparece regulado como monopolio señorial de la Orden en el mencionado fuero de Miguelturra ${ }^{97}$.

\footnotetext{
93 AHN, OO.MM., sign. 1412c, fol. 30r.

94 AHN, OO.MM., leg 6.075, n. ${ }^{\circ} 1$, fol. $72 r$.

95 AHN, OO.MM., leg 6.109, n. ${ }^{\circ} 22$, fol. 174 r.

HINOJOSA, Documentos, pág. 149.

lbid.
} 
A finales del siglo $\mathrm{XV}$, se encontraban entre las propiedades de la encomienda de Calatrava la Vieja la bodega y los lagares que había en las casas de El Turrillo ${ }^{98}$. En concreto se trataba de una bodega de doce tapias y media de largo y tres de alto, dentro de la cual había dos lagares con sus pilas respectivas ${ }^{99}$.

\section{LA ORGANIZACIÓN ECLESIÁSTICA DE CALATRAVA LA VIEJA}

En principio, se podía considerar que en materia de jurisdicción eclesiástica el territorio de Calatrava era heredero de la antigua diócesis visigoda de Oreto ${ }^{100}$. Sin embargo, la restauración del obispado visigodo contaba con la decidida oposición del arzobispo de Toledo, que vería así cercenadas sus posibilidades de crecimiento meridional. Por eso, en abril de 1148 el papa Eugenio III incluyó a la villa de Calatrava entre los oppida que integraban la jurisdicción eclesiástica de la diócesis toledana ${ }^{101}$. En 1218, tras el paréntesis de la etapa de dominio almohade, y para evitar dudas sobre la jurisdicción eclesiástica del Campo de Calatrava, el papa Honorio III confirmó a la Iglesia de Toledo la pertenencia del lugar e iglesia de Zuqueca, que en aquelia época era considerado erróneamente como el emplazamiento de la antigua ciudad episcopal de Oreto ${ }^{102}$.

No obstante, los problemas habían surgido con anterioridad, como consecuencia de que el territorio comprendido entre los Montes de Toledo y Sierra Morena pasó a poder de la Orden de Calatrava, ya que los freires estaban exentos del pago de diezmos y primicias de las tierras directamente trabajadas por ellos, según recogía la bula fundacional de la Orden. Esta circunstancia propició el enfrentamiento entre los calatravos y la sede toledana. Para resolverlo se alcanzó un primer acuerdo en diciembre de 1183, por el que el maestre calatravo y el arzobispo toledano se repartían los derechos eclesiásticos ${ }^{103}$. Sin embargo, la progresión de la población

98 AHN, OO.MM., leg. 6.109, fol. 174v.

99 AHN, OO.MM., leg. 6.109, fol. 123v-124r.

100 Sobre la evolución de este obispado visigodo vid. Gregorio de ARGÁlz, La soledad laureada por San Benito y sus hijos en las Iglesias de España, 1, Madrid, 1675, fol. 168v-178; Enrique FlóREZ, España Sagrada, Theatro geographico-historico de la iglesia de España, VII, Madrid, 1751, págs. 263-272; y Demetrio MANSILLA Reoyo, Geografia eclesiástica de España. Estudio histórico-geográfico de las diócesis, 2 vols., Roma, 1994, l, págs. 283-284.

101 Biblioteca Nacional, manuscrito 13.093, fols, 127-128. Cfr. J.F. Rivera Recio, La lglesia de Toledo en el siglo xil (1086-1208), I, Roma, 1966, págs. 80-81.

102 Publ. Demetrio Mansilla, La documentación pontificia de Honorio III, Roma, 1965, págs. $25-26$

103 AHN, Códices, sign. 996B, fol. 17v. Publ. Ortega y Cotes, Bullarium, pág. 20. 
en el primer tercio del siglo xIII propició el crecimiento de las antiguas parroquias fronterizas y la creación de otras nuevas, con el consiguiente despertar de los conflictos entre los calatravos y el arzobispado de Toledo ${ }^{104}$.

El nuevo enfrentamiento se inició en la década de 1230, prolongándose a lo largo de casi tres lustros. Varias bulas papales intentaron buscar el acercamiento entre ambas partes ${ }^{105}$, que no se alcanzaría hasta mayo de 1245. El acuerdo volvía a reiterar parte del compromiso de 1183: la Orden debía entregar al arzobispo la tercia pontifical de las parroquias de sus señoríos, reservándose las dos tercias de las iglesias correspondientes a la fábrica y clérigos, con la aclaración de que en las iglesias de Calatrava la Vieja y su término, desde la azuda del Emperador hasta Zacatena, el arzobispo mantendría el diezmo íntegro. En cualquier caso, todos los párrocos quedarían sometidos a la jurisdicción diocesana. Las penas de los sacrilegios se repartirían por la mitad entre la Orden, por una parte, y el arzobispo y el arcediano correspondiente, por otra. Sin embargo, los calatravos debían entregar una procuración de cuatro días y entre 50 y 60 «bestias» al arzobispo y diez días de procuración - siete al norte del Guadiana y tres al sur-y ocho «bestias» al arcediano. Estas dos dignidades de la Iglesia toledana tenían también derecho a recibir un maravedí anual en concepto de catedrático en aquellas aldeas que superasen los diez pobladores casados, no quinteros ${ }^{106}$.

A mediados del siglo XIII, la red parroquial de las tierras limítrofes a Calatrava la Vieja había experimentado un cierto crecimiento. Para entonces, además de las iglesias de la propia villa, podemos reseñar la existencia

104 Sobre esta conflictiva relación vid. J.F. O'CALLAGHAN, «The Order of Calatrava and the Archbishops of Toledo, 1147-1245», Studies in Medieval Cistercian History presented to Jeremiah F. O'Sullivan, Spencer, Massachussets, 1971, 63-87; H. GrassotTI, «En torno a las primeras tensiones entre las Ordenes militares y la Sede Toledana". Annales de Historia Antigua y Medieval, 17 (1972), 155-169; Raquel TORRES JiMÉNEZ, «Organización eclesiástica», La provincia de Ciudad Real. II. Historia, Ciudad Real, 1992, 221-243; Id., "Modalidades de jurisdicción eclesiástica de los dominios calatravos castellanos (siglos XII-XIII)", en Ricardo IZQUIERDO BENITO y Francisco RUIZ Gómez (Coordinadores), Actas del Congreso Internacional conmemorativo del VIII centenario de la Batalla de Alarcos, Cuenca, 1996, 433-458.

105 Documentos de 23 de marzo de 1233 (Archivo Histórico Nacional, Sellos, cajón $5, n{ }^{\circ} 19$ ); 6 de noviembre de 1236 (publ. L. AuvraY, Les registres de Grégoire IX, 4 vols., París, 1898-1908, II, n. ${ }^{\circ} 3374$; J. GorosterRatzu, Don Rodrigo liménez de Rada, gran estadista, escritor y prelado, Pamplona, 1925, pág. 452); 8 de noviembre de 1236 (M.R. ZAPATER, Cister militante, Zaragoza, 1662, pág. 213); 29 de enero de 1239 (publ. Auray, Les Registres de Grégoire IX, II, n. ${ }^{\circ}$ 4717; Gorosterratzu, Don Rodrigo, págs. 456-457; traducción en Zapater, Cister militante, págs. 214215); y 4 de mayo de 1240 (publ. ORTEGA Y COTES, Bullarium, págs. 71-72)

106 Publ. ORtega y COTES, Bullarium, págs. 78-82; Hilda Grassottl, «Don Rodrigo Ximénez de Rada, gran señor y hombre de negocios en la Castilla del siglo XIII», Cuadernos de Historia de España, 55-56 (1972), págs. 296-301. Resumen amplio en F.J. HeRnández, Los cartularios de Toledo. Catálogo documental, $2 .^{a}$ edición, Madrid, 1996, n. $^{\circ} 477$. 
de parroquias en Miguelturra, Membrilla, Carrión, Torralba y, probablemente, Fernáncaballero.

La organización eclesiástica del Campo de Calatrava se mantuvo de manera similar a lo largo de toda la Edad Media. Solamente, al final del período, un acuerdo puntual entre el arzobispo de Toledo y el maestre de Calatrava, modificaba el reparto de jurisdicción eclesiástica en algunos lugares de la comarca. La avenencia tuvo lugar en enero de 1482 y afectaba a algunas zonas relacionadas con Calatrava la Vieja del siguiente modo:

Item se averiguo, que de las viñas puestas, e que se pusieren en el Termino del Turrillo, e Carrion, e lo que se labrare por pan en el quarto que dicen de la Serrezuela, y se limita, y parte como viene el camino de Ciudad Real para la Dehessa de Zacatena, que atraviessa el camino que va de Carrion a la dicha Serrezuela, que torna el dicho camino a man derecha el mas cercano de la dicha Serrezuela acia Carrion, que de aquel termino, e quanto se debe terzolar del pan, y del vino que se cogiere en las viñas susodichas, e de lo otro que queda, se averiguo, y fallo ser Dehessa antigua, $e$ haver diezmado, $y$ que debe diezmar de aqui adelante entreramente sin terzuelo alguno al dicho señor Maestre, y a quien por su Señoria lo oviere de haber ${ }^{107}$.

No obstante, desde casi un siglo antes, concretamente en 1397, la Orden de Calatrava había consolidado una red de prioratos, encargada de atender las necesidades religiosas de los miembros de la Orden. Se constituyeron, tal y como hemos visto anteriormente, un total de seis prioratos en el Campo de Calatrava. El ámbito de Calatrava la Vieja quedó a cargo del priorato de Nuestra Señora de los Mártires. Se iniciaba así un camino hacia la autonomía en materia de jurisdicción eclesiástica que culminaría a principios del siglo XVI, cuando el prior de Calatrava fue dotado de funciones similares a las de los obispos en su territorio. Sin embargo, mientras las competencias eclesiásticas aumentaron, el número de prioratos se redujo considerablemente. En el siglo XVI ya sólo quedaban tres prioratos en el Campo de Calatrava: Fuencaliente, Zuqueca y el Sacro Convento de Calatrava ${ }^{108}$.

107 Publ. Ortega y Cotes, Bullarium, pág. 280.

108 Sobre esta cuestión, que excede el marco cronológico y temático de este trabajo, vid. Francisco FERnández IZQUIERdo, La Orden militar de Calatrava en el siglo XVI. Infraestructura institucional. Sociología y prosopografia de sus caballeros, Madrid, 1992. págs. 65-70 y 158-164. 


\section{APÉNDICE DOCUMENTAL}

1471, octubre 8 , lunes

Pedro Morales, comendador de Fuente del Emperador, y Diego de Loaysa, comendador de Valdepeñas visitan la encomienda de Calatrava la Vieja.

AHN, OO.MM., leg. 6.075, n. ${ }^{\circ} 1$, fol. 71v-72v.

Visitaçión de las casas de la encomienda de Calatrava que están en El Turrillo/

A lunes, veynte e ocho días de otubre, año del nasçimiento de nuestro Señor lhesu-/cristo de mill e quatroçientos e setenta e un años. Yo/ frey Pedro Morales, comendador de la Fuente Emperador, e frey Diego de Loaysa, comendador de Valdepeñas, visitadores de la Orden/ por nuestro señor el maestre, venimos a visitar las/ casas de la encomienda de Calatrava que está[n] en El Turrillo,/ de que es comendador frey Gonçalo de Luso, e fallamos/ que en la entrada de la puerta está una portada/ grande de cal e canto e piedras, e labradas con unas/ puertas de portaleñas de pino con sus tirantes de/ pino, con buen clavasón, con su aldaba de fierro. Ençima/ de la dicha puerta una tapia enlusida e un tejado en-/ çima cubierto de su buena madera e teja. E luego, a la/ mano derecha de la entrada, está un aposentamiento, e sube/ a él por una escalera de piedra e por ella entran a un/ como portal colgadiso a un agua e por el entran por una/ puerta grande a una torre e ençima de esta puerta están/ las armas del maestre nuestro señor. La qual torre está entormada/ e cobierta de tirantes e ripia, e por ésta sube luego/ por una escalera de madera a la bóveda de ençima \% Tiene la dicha bóveda el suelo de ladrillo de cal e con dos/ventanas con sus puertas e un aparador de madera a la/ mano derecha. E cubierta esta torre ...... de sus tirantes e quarto-/ nes e ripia e todo ello de su buena teja e enlusida. De esta/ torre a la mano ysquierda está otra cámara buena con una $/ /^{2 r}$ (roto) que ..... una chimenea francesa e un (roto)/ madera para dormitorio e todo este aposentamiento blanqueado/ de cal e con sus puertas de pino, a todos los logares/ que son menester. E luego a la mano derecha de la torre, en lo baxo, una/ puerta que sale al campo, e luego, en par de ésta, a la misma/ mano está una nave pequeña. E adelante está en par de ella/ una casa de madera parda e tejada e/ es estancada e a la ysquierda e/ a la mano derecha de madera de pino de/ tirantes e ripia e dos troxes/subrades con su madera de ripanes/ de pino e esta casa guarneçida de sus puertas 
de pino./ E luego en par de ésta, otra casa pequeña como despensa/ cubierta de su madera de pino e un entresuelo de tirantes/ e ripia con sus puertas de pino. E luego sigue la misma/ mano junto a ella está otra casa cubierta de su madera e teja/ e en ella está un atajo en medio de tapias, en el qual atajo ay/ una pesebrera paras bestias e de la otra parte un horno e luego/ junto con ésta una casa de gallinas cubierta de madera/ e carriso. $E$ luego a par de esto está un corral grande en el/ qual está una casa pajar cubierta de madera e carriso e retama./ E luego a la mano ysquierda de la entrada de la dicha casa/ está una casa grande e larga en que avía dies e siete/ tapias en largo e tres tapias en alto e el ancho cubierta de/ soldada e madera parda e su teja, e ay en ella tres aparta-/ mentos, uno para cosina e los dos para establos e/ a la mano derecha a la entrada de la dicha casa está una puerta cubierta de grano, la qual tiene las puertas de/ red de pino con su entresuelo de madera, sobre la qual puerta/ está un portal colgadiso cubierto de madera de pino e/ cubierto de teja e en cerradura de ......

Ynventario de los bienes e posesiones e rentas e propios e quantas cosas pertenesçientes/ encomienda de Calatrava que está en El Turrillo, de que es comendador frey Gonzalo de Luso./

Primeramente tiene la dicha encomienda la dehesa de Calatrava que es/ arrendada de ynvierno e de verano por çinquenta e tres/ mill e quinientos maravedís./

Tiene más la dehesa del Turrillo con la Çeladilla de ynvierno/ e verano que es arrendada por XXV mil, e el diesmo de ella que/ del pagase se hará le pertenesçe al comendador una parte de ello.//72v

Tiene más que le pertenesçe los posos del barro de la Orden/ que había en Çibdad Real, los olhios./

Tiene más que le pertenesçe el río de Guadiana e pesca,/ en quanto duran los términos de Calatrava, que se arrendó en/ II mil./

Tiene ${ }^{b}$ más la renta del esparto que se saca/ a vender en hebra, que se arrendó por II mil./

Tiene más que le pertenesçe las menunçias/ de Carrión que no están arrendadas./

Tiene más un yantar que le ha de dar por/..... los del conçejo de Carrión cada año./

Tachado: La qual.

b Margen izquierdo: Turrillo. 
Tiene más otro yantar en Hernáncavallero e de cada/ casa una gallina e por la dicha yantar çient maravedís./

Pertenésçele más en el dicho logar Hernáncavallero la montara-/ zía de pasades de colmenares e otras cosas./

Pertenésçele ${ }^{c}$ el diesmo de las viñas de los vesinos de la dicha/ Çibdad Real e de Carrión que ya en el término del Turrillo/ y que podrá ser un año con otro seysçientas arrobas de vino.

Tiene más que le pertenesçe la mitad de pie de altar de/ Carrión e las penas e caloñas de allí e de Hernáncavallero/ e de las dehesas e términos de Calatrava e del Turrillo/ e de Carrión el diesmo de pollo e ansarones e lechones./

Tiene más que está en la casa bodega del Turrillo que son de la / Orden çinco cubas robreñas e tinajas, veynte/ e tres que ha comprado el dicho comendador.

1477, marzo 6. Carrión

Fedro Benegas, comendador de Calatrava la Vieja, cede a Alfonso Martínez, vecino de Fernáncaballero, el molino que tiene la encomienda en el arroyo de Bañuelo, a cambio de un censo anual de dos pares de buenas gallinas y la condición de construir en el molino los rodeznos que fueran posibles.

AHN, OO.MM., leg. 6.110, n. ${ }^{\circ} 23$, fol. 86. (Traslado fechado en Malagón, el 9 de agosto de 1510).

Sepan quantos esta carta de un çenso vieren como yo frey Pedro Vanegas, co-/ mendador de la encomienda de Calatrava la Vyeja, con todas las cosas/ pertenesçientes a ella, que yo así como poseedor de las rentas/ de ella, otorgo e conosco que do a vos Alfonso Martínez, el mayor, veçino/ de Hernáncavallero, lugar e jurediçión de la Horden de Calatrava,/ una parada de molino que la dicha mi encomienda ha e tiene/ que es en el arroyo que dyzen de Alvañuelo, la qual dicha parada cae en/ la dehesa boyada, término del dicho lugar, la qual dicha parada vos do a çenso/ e en

Margen izquierdo: vino de Carrión.

d Sic. 
nombre de çenso para que vos el dicho Alfonso Martínez e vuestros fijos here-/ deros e vuestros deçendyentes de vos e de ellos o quien lo poseyere adefiçar/ e adefiçedes un rodesno o dos o sy más copyere la dicha casa e quien/ adefiçades o adefiçen los dichos vuestros fijos e herederos e sus deçendien-/ tes de ellos e la podades e puedan vender e vendades quier adefyça-/ da quier no a la persona o personas que más vos dieren por ello tanto,/ que no sea clérigo ni onbre poderoso, e sy lo ovyerdes e vender e vendiyere/ que al enpenar e enpenaren con que vos el dicho Alfonso Martínes e los dichos vuestros/ herederos e sus deçendientes de ellos e los que compraren la dicha parada aya-/ des a pagar e paguen e dedes e paguedes en cada un año de çenso e en/ nombre de çenso a mí el dicho comendador o a quien por mí lo ovyere de/ aver e de recabdar e al comendador o comendadores que después de mi/ vynieren dos pares de gallinas buenas tales que sean de dar e de tomar éstas/ se alimentar que ha de ser myas, que yo non vos puedo quitar ni quitare, ni otro/ por $\mathrm{mi}$, ni los comendadores que después de mí vynyeren a la dicha villa e los adefiçios que en ella tovierdes e tovieren fechos e uso e costumbre de ribera/ por vuestra vida e de vuestros fijos e sus deçendientes e de aquel $o$ aquellos/a quien lo vendierdes e enpenardes o vendyeren o enpenaren todavya/ pagando en cada un año los dychos dos pares de gallinas del dicho çenso./ E yc el dicho Alfonso Martynes, otorgo e conosco que reçeby e tome e recibo e tomo en mí mismo la dicha parada en el dicho arroyo por la vya/ e forma susodicha e por esta carta de çenso me obligo por mí mismo e/ por todos mis byenes muebles e rayzes avydos e por aver de no dexar el/ dicho çenso e parada por la dicha mi vyda e de los dichos mis fijos e desçen-/ dyentes de ellos, so pena sy la dexar quisyere o quisyeren que los dichos mys/ byenes queden obligados al dicho çenso e que es el plazo a que vos tengo e/ tenemos a dar e pagar el dicho çenso en cada un año por el dya de la/ fecha de Santa María para lo qual e syn tener e guardar e complir do e otorgo/todo mi poder complido a la dicha Horden e uso de ella. Testigos que fueron presen-/ tes a todo lo susodicho e otorgamiento de esta carta: Alfonso de Araus,/ cryado del señor comendador, e Antón Martynes de Hernáncaballero e Fer-// $/{ }^{86 \mathrm{v}}$ nando de Almagro. E yo el dicho frey Pero Vanegas, comendador susodicho/ me obliguo de vos dar a vos el dicho Alfonso Martínes Mayor/ una carta del maestre de Calatrava mi señor para en favor e ayuda/ del dicho çenso sy neçesario la ovyerdes e me requirierdes que vos la/ de ganada a mí costa e misyón e demás, e allende por esta/ carta me obliguo de vos defender e anparar en toda mi vyda en/ la dicha parada e çenso e de vos la non quetar por más ni por menos ni por el tanto que a vos ni a los vuestros fijos e deçendyentes de ellos,/ so pena de vos pechar e paguar la dicha parada con el/ ade- 
fiçio o adefiçios que en ella ovyerdes os ovyeren fecho/ no llegando ni fazyendo descargo de las rentas de los años/ pasados para lo qual asy tener e guardar complir yo el dicho comen-/ dador obliguo a mí mismo e a todos mis byenes pertenençientes a la dicha mi encomienda. $E$ yo el dicho Alfonso Martínes a mí mismo/ e a todos mis byenes muebles e rayzes avidos e por aver. E/ por que esto sea firme e non venga en dubda otorgamos esta carta ante escribano/ e testigos yuso escritos e corre la dicha renta e çenso desde oy día de la/ fecha de esta carta, que es fecha e otorgada en Carrión, lugar e jurediçión/ de la Horden de Calatrava, syes días del mes de março, año del nasçi-/ miento del nuestro Salvador Ihesucristo de mill e quatroçientos e setenta e/ syete años. Testigos los susodichos. E yo Alfonso Ruys, escribano publico/ en el dicho lugar, a la merçed del maestre mi señor, que a todo lo/ susodicho presente fuy en uno con los dichos testigos de ruego e/ otorgamiento del dicho señor comendador e del dicho Alfonso Marty-/ nes e esta carta por otro fyze e escribí según que ante mí paso/ e soy andete sygo por ende en testimonio de verdad fyz/ a quien este mío sygno a tal. Alfonso Ruyz de Almagro,/ escribano.

1493, marzo 17

Juan de Almagro, sacristán del convento de Calatrava, y Pedro de Aguayo, comendador de Bívoras, visitan la encomienda de Calatrava la Vieja.

AHN, OO.MM., leg. 6.109, $n .{ }^{\circ} 22$, fol. 174r-175r.

Calatrava la Vieja, 19 de marzo 1493./

Visytaçión de la encomienda de Calatrava que fallamos en los libros de la/ visytaçión ser su asyento e morada en El Turrillo./

En XVII días del mes de março de MCCCCXCIII años, yo frey Juan/ de Almagro, sancristán del convento de Calatrava, e yo frey/ Pedro de Aguayo, comendador de Bívoras, visitadores de la Horden e caba-/ llería de Calatrava, por los muy altos e muy poderosos el rey/ e la reyna, nuestros señores, administradores perpetuos de ella por/ bula apostólica, venimos a visytar las casas de la encomienda/ de Calatrava que son en El Turrillo y fallamos todos los ede-/fiçios que el comendador Gonçalo de Luzio, de la/ encomienda de Calatrava, avía fecho y hordena-/ do e sostenido, morando i estando en ellas/ segúnd en las visytaçiones antiguas está 
a-/sentado, muchos de ellos caydos e la casa sola e des-/ anparada, en espeçial el tejado de ensomo de la puerta/ prinçipal destejado y descobierto.l

En el quarto prençipal, a la mano derecha, está hondido el/ portal delante del aposentamiento e sala prençipal e el retrete del ansy-/ mesmo con la chimenea que tiene todo caydo./

Ansymismo, entrando por la puerta declarada están/ dos casas, la una de despensa e una establía, mal-/ tratados e syn puertas con otra casa que está/ entre éstas sobredichas e la bodega la mlayor/ parte de ella hondida, e todas las otras paredes ansy/ de la dicha casa como huerta e corral, todas maltratadas/ e sin bardar, e ansymesmo la casa del horno ca$/$ yda e descubierta. A la mano ysquierda está una/ bodega con dos jarayzes la qual por no se poder aver/ las llaves de ella no se pudo ver las cosas que tenía/ dentro como quiera que su cobertura de ella está buena/ la qual está a cargo de los retadadores, $/ /^{174 v}$ en la qual se dize e ovymos ynformaçión que/ están dentro XVIII tinajas e syete cubas,/ las quales en las visytaçiones antiguas se/ falla asentado por casa de serviçio de la en/ comienda e la bodega e lagares estaban en otra/ casa de fuera que está agora cayda./

Ansymismo vymos el cuerpo/ de la yglesia cayda a la mitad de la capilla,/ e de ella quitada la teja por cobrir/ la bodega e llevadas las canpanas/ de la dicha yglesia de las quales no se pudo aver/ ynformaçión de quién las oviese llevado. E/ ansymesmo vymos un palomar en la/ dicha casa descubierto e maltratado, lo qual todo/ vysytando la dicha casa fallamos que por los/vysytadores pasados fue mandado reparar/ e sostener al comendador frey Sancho de Soto//175r

Inventario de los bienes e rentas e posesyones y otras cosas pertenesçientes a la/ encomienda de las casas de Calatrava la Vieja que son en El Turrillo./

Primeramente/ tiene la dicha encomienda la dehesa de Calatrava de invierno y verano./

Tiene más la dehesa del Turrillo con la Çela-/ dilla que le pertenesçe, invierno y verano./

Pertenésçele más el medio diesmo del ga-/ nado que nasçe e se cría en la Çeladilla./

Tiene más la renta del barro que labran los/vezinos de Çibdad Real./

Pertenésçele el río de Guadiana e pesca quanto duran los/términos de Calatrava./ 
Tiene más que le pertenesçe las minunçias de Carrión./

Tiene más una yantar en Carrión que ha de dar el conçejo/ e ochenta maravedís cada año./

Tiene más la renta del esparto que se saca a vender en hebra./

Tiene más que le han de dar en Fernándcavallero por otro yantar çient maravedís e más cada vesino una gallina./

Pertenésçele en el dicho lugar e sus términos los diesmos/ de los colmenares./

Pertenésçele más los diesmos de las viñas de los vesinos de/ Carrión e Villa Real que están en término del Turrillo./

Tiene más el diesmo de las pyñas de los pynos que están/ en los colmenares, en el término de Fernándcavallero, e/ penas e calonias del dicho lugar./

Pertenésçele más el pie de altar de Carrión e las penas e/ calonias de las dehesas e términos de Calatrava e del Turrillo./

Tiene más la dehesa de la Çelada./

Tyene más que le pertenesçen las sernas del Turrillo./

1493, marzo 18

Los visitadores Juan de Almagro, sacristán del convento de Calatrava, y Pedro de Aguayo, comendador de Bívoras, mandan a Sancho Sotomayor, comendador de Calatrava la Vieja, que repare las casas de EI Turrillo, residencia habitual de los comendadores.

AHN, OO.MM., leg. 6.109, n. ${ }^{\circ} 22$, fol. 176.

Mandamiento para el comendador de Calatrava la Vieja que repare las Casas del Turrillo./

Yo frey Juan de Almagro, sancristán del convento de Calatrava, e yo frey/ Pedro de Aguayo, comendador de Bívoras, visitadores de la Horden e caballería/ de Calatrava por los muy altos e muy poderosos el rey e la rey-/ na, nuestros señores, administradores perpetuos de ella por bu-/ la apostólica, fazemos saber a vos frey Sancho/ de Sotomayor, comendador de Calatrava la Vieja,/ que por quanto visitando la dicha vuestra encomienda/ de que vos soys comendador, no vos fallamos,/ ni las casas del 
Turrrillo donde los comenda-/ dores vuestros antepasados solían estar a/ morar, antes las fallamos desoladas e caydas,/ ni fallamos nin conosçimos otro lugar ni/ asyento que los dichos comendadores de ella debiesen tener/ e morar, salvo las dichas casas del/ Turrillo donde de luengos tiempos aquellos estobieren/e en los libros de las visytaçiones se falla aver/ morado e sostenido. Ansymesmo falla-/ mos la yglesia cayda e muy maltratada, e muda-/ da la bodega e lagares a la dicha casa. E la/ otra casa que solía ser bodega cayda por el /suelo porque por remedio e reparo de ello de/ parte de sus altezas vos mandamos que luegos vos/ vengáys syn otra dilaçión a regidir e estar/ de continuo en ellas o pongays alcayde o mo-/ rador que las tenga linpias e bien tratadas como dicho es ${ }^{\mathrm{a}}, / /^{176 \mathrm{v}}$ reparándolas e refaziéndolas, e que todo lo que neçesario/ fuere como pastrimonio de la Horden, e ansymismo/ fagáys cobrir e sostener la dicha yglesia fazién-/ dole tornar e volver las campanas donde quier que se/ fallaren e otras quales quier cosas de ella podiendo/ se aver ynformaçión de ello de quien quier que los aya/ llevado $o^{\mathrm{b}}$. I

Y por quanto las cosas en el dicho mandamiento conte-/ nidas, ni alguna de ellas no hallamos complidas, ovi-/ mos de vos mandar enbargar e se gastar de las/ rentas de la dicha vuestra encomienda en contya de seys mil maravedís/ que nos paresçió ser nesçesario para faser e cobrar las sobredichas/ cosas. Por tanto mandamos vos que no cobres ni resçibaes los/ dichos maravedís vos ni otro por vos./

$Y$ con esto mandamos y encomendamos todas las otras cosas/ que vos vieredes de reparar y gastar en las heredades e posesiones/ de la dicha vuestra encomienda y sy algunas cosas supieredes/ estar perdidas 0 enajenadas trabajar con todas fuerças por lo/ redimir e cobrar como sois obligado. $Y$ thener en vuestras ar-/cas e con vos los inventarios claros de las heredades e pose-/ syones pertenesçientes a la dicha encomienda y renovarlas ca-/da año según sois obligado y asentar en ellos todos/ e quales quier bienes inmuebles que antes de venir a la Horden e des-/ pués acá avéys avydo e tenéys, por quanto todos los tales bienes/ pertenesçen a la Horden. E asymismo vos mandamos que tengáys/ las definiçiones e manto de Horden e las leáys e vos ynforméys/ para las guardar e nos hagáis enviar, e cómo e dónde/ reçebís las sacramentos en las tres pascuas del año, e la/ relaçión e dispusyçión de vuestro inventario como lo tenéys

a Margen derecho: En la visitaçión pasada a vos/ fue mandado vos viniésedes/ a resydir e estar en ellas de/ continuo o pusiésedes ende/ alcayde o persona que morase/ en ellas que las limpiase e/ toviese aderescadas, lo qual/ hallamos no aver hecho ni/ conplido antes de causa de la/ soledad está todo muy/ más dapnado y perdido.

- Tachado: y ni era manera sedçetado. 
fecho,/ e ansymimo nos enbíes como conplís las cosas acordadas/ en la espediçión del capítulo que se çelebró en Santa Fe que sus/ altesas mandaron notificar e mostrar a los dichos comendadores/ por quanto aquello quieren y mandan que se cumpla de lo qual como/ dicho es nos mandad enviar fe al capítulo que sus altesas/ tienen asyngado a los de Horden por nuestro descargo e/ nuestro. Lo qual todo que dicho es de partes de sus altesas vos requeri-/ mos e mandamos y de la manera encargamos fagáys e cumplá-/ is çegúnt justo e legítimo impedimento. En otra manera será/ forçado de lo remediar según los estatuos e difyniçiones/ de la Horden lo dispone. En testimonio de lo qual damos este mandamiento para vos firmado de nuestros nombres e de Juan de Pastrana, escrivano de nuestra visytaçión, que es fecho en XVIII dí-/ as del mes de março de MCCCCXLIII años.

1493, marzo 19

Los visitadores Juan de Almagro, sacristán del convento de Calatrava, y Pedro de Aguayo, comendador de Bivoras, mandan a Alfonso Calvillo, comendador de Daimiel, que tome 10.000 maravedís de las rentas de la encomienda de Calatrava la Vieja para reparar los edificios que ésta tiene en El Turrillo.

AHN, OO.MM., leg. 6.109, n. ${ }^{\circ} 22$, fol. 177.

Mandamiento para el comendador de Daymiel para que tome e resçiba dies mill maravedís de las/ rentas que tiene a cargo de frey Sancho de Sotomayor, comendador de Calatrava la Vieja, y de los/ maravedís de pensyón que frey (blanco) Chacón lleva de las rentas de la dicha encomienda para sos-/ tener los edefiçios de las casas e asyentos que la dicha encomienda tiene en El Turrillo./

Yo frey Juan de Almagro, sancristán del convento de Calatrava, e yo frey Pedro de/ Aguayo, comendador de Bívoras, visytadores de la Horden - cavallería de Cala-/ trava por los muy altos e muy poderosos el rey e la reyna, nuestros señores, / administradores perpetuos de ella por bula apostólica, fasemos saber/ a vos frey Alonso Calvillo, comendador de Daymiel e Xetar, que visytando la encomi-/ enda de Calatrava la Vieja de que es comendador frey Sancho de Sotomayor, que vos tenéys/ en cargo por mandado de sus altesas, hallamos que los viytadores pasados/ mandaron al dicho frey Sancho de Sotomayor que morase y estoviese en las 
casas/ del Turrillo donde los comendadores antepasados solían estar o que hisyese poner/ en ellas un alcayde o persona que morase allí, e las limpiase e re-/ parase e rehiziese todo lo nesçesario, sosteniendo la yglesia e ha-/ ziendo volver allí las campanas e otras quales quier cosas que de allí se han/ llevado por manera que aquello se sostuviese como convenía al patri-/ monio de la Horden. Lo qual no hallamos al dicho comendador averlo hecho asy,/ de cuya carga los edifiçios están muy dañados y perdidos e solos que no/ moran ni están allí nadie. Antes hallamos tomada e comprada una casa/ que sirve de cozina y establo para bodega en que se resçibe y está la terçia del vino,/ que es de la mesa maestral, porque para remedio de sostener lo que/ agora ay nos paresçió que se devía envargar algunos maravedís de las rentas/ en tanto que en el capítulo primero por nosotros se hase relaçión e se/ provea como sus altesas entiendan que cumple a su serviçio e al bien/ de la Horden. Por tanto de su parte vos mandamos y de la nuestra mucho encarga-/ mos que de quales quier maravedís de las rentas de la dicha encomienda que primero se deviere hagáys/ gastar en los reparos que vos vieredes ser más nesçesarios para que los di-/ chos edifiçios sean sostenidos fasta en contía de dies mil maravedís/ en esta manera: de las rentas que vos resçebís e tenéys a cargo de cobrar por el/ dicho comendador los syes mil maravedís y de las çinquenta mil maravedís que el comendador de Talavera/ (blanco) Chacón tiene de pensyón en la dicha encomienda, los otros quatro/ mil maravedís de los quales dar cargo a persona de buen recabdo que los haga/ gastar en los dichos reparos que más fueren menester e vos de cuenta de ello/ como a vos mejor paresçiere e vieredes que cumple para se sostener//177v. E por la presente mandamos a quales quier personas que tienen arren-/ dada qualesquier rentas pertenesçientes a la dicha encomienda que/ de qualesquier maravedís que agora deven o devieren, asy al dicho comendador/ frey Sancho de Sotomayor como al dicho frey (blanco) Chacón, comendador de Tala-/ vera ${ }^{a}$, que vos acuda con los dichos/ dies mil maravedís según como dicho es con aperçebimiento que se/ los dieren e pagaren a los dichos comendadores o a otras/ personas por ellos los tornaren a pagar/ otra ves de sus propios bienes. El qual dicho/ comendador de Talavera mandamos de parte de sus altesas que no resciba ni cobre de los dichos arrendadores/ ni de algunos de ellos los dichos quatro mil maravedís, antes que los/ resçiba e pase en cuenta a aquel o aquellos de quien los ovie-/ re de aver por rasón de la dicha pensyón, asy para cobrar/ los dichos maravedís de los dichos arrendadores o qualesquier de ellos o

a Tachado: por rasón de la dicha pensyón. 
otra qualquyer cosa/ fuere menester por la presente vos damos poder e facultad/ para ello según lo avemos e tenemos de sus altesas e/ Horden con todas sus inçidençias. $E$ en testimonio de lo/ qual dimos este mandamiento firmado de nuestros nombres/ e de Juan de Pastrana, escribano de nuestra visytaçión, que es fecho en dies e nueve días del mes de março, año del nasçimiento/ de nuestro Salvador Ihesucristo de mil e quatroçientos e noventa e tres años.

1502, febrero 15. Almagro

Pedro de Aguayo, comendador de Malagón, y Pedro de Troya, prior de San Benito de Sevilla, visitan la encomienda de Calatrava la Vieja.

AHN, OO.MM., leg. 6.110, n. ${ }^{\circ} 2$, fol. 54

15 de febrero, Calatrava la Vieja, 1502./

Visytaçión de la encomienda de Calatrava la Vieja que fallamos en los libros/ de la visytaçión ser su asyento e morada en El Turrillo./

En Almagro, quinse días del mes de febrero de 1502/ años. Este día, yo frey Pedro de Aguayo, comendador de Ma-/ lagón, e yo frey Pedro de Troya, pryor de Sann Be-/ nito de Sevilla, capellán de sus altesas, visytadores/generales de la Orden e cavallería de Calatrava por los/ muy altos e muy poderosos e cristianísimos el rey e/ la reyna, nuestros señores, administradores perpetuos/ de ella por bula apostólica, venimos a ver e visyI tar las casas e asyentos de la encomienda de Calatrava/ la Vieja que son en El Turrillo y fallamos todos los/ edefiçios antyguos estantes e segúnd e de la manera/ que en los libros de la visytaçión pasada están asen/ tados çerca de lo qual se proveyó lo que adelante/ en su mandamiento será obtenido por frey Pedro Véles/ de Jahén, comendador que agora fallamos que es de la dicha/ encomienda.//54v

Ynventario de los bienes e rentas e posesyones e otras cosas pertenesçientes a la/ encomienda de las casas de Calatrava la Vieja que son en EI Turrillo.

Primeramente/ tiene la dicha encomienda la dehesa de Calatrava de ynvier-/ no e verano./

Tiene más la dehesa del Turrillo en la/ Çeladilla que le pertenesçe de ynvierno e verano./ 
Pertenésçele más el medio diesmo del/ ganado que nasçe e se cría en la Çeladilla./

Tiene más la renta del barro que labran los veçinos de Çibdad/ Real./

Pertenesçele el ryo del Guadiana e pesca quanto/ duran los dominyos de Calatrava/

Tiene que le pertenesçen las menuçias de Carrión./

Tiene más un yantar en Carrión que ha de dar el conçejo de Carrión/ e ochenta maravedís cada año./

Tiene más la renta del esparto que se saca a vender en hebras./

Tiene más que le ha de dar en fuerça de ello por otro yantar/ çient maravedís e más cada vesino una gallina./

Pertenésçele en el dicho lugar e sus términos los diesmos/ de los colmenares./

Pertenésçele más los diesmos de las viñas de los veçinos de/ Carrión e Villa Real que están en término del Turrillo./

Tiene más el diezmo de las pyñas de los pinos que están/ en los colmenares en el término de Hernáncavallero y pe-/ nas y calopnias del dicho lugar./

Pertenésçele más el pie de altar de Carrión e las penas/ y calopnias de las dehesas e términos de/ Calatrava e de Turrillo./

Tiene la dehesa de la Çelada./

Tiene más que le pertenesçen las sernas del Turrillo./

Pertenésçele poner el cura en la iglesia de Carrión como/ benefiçiado de la dicha yglesia.

1502, febrero 15. Almagro

Los visitadores Pedro de Aguayo, comendador de Malagón, y Pedro de Troya, prior de San Benito de Sevilla, mandan a Pedro Vélez de Jaén, comendador de Calatrava la Vieja, que construya o compre en la villa de Carrión unas casas para utilizarlas como residencia de los comendadores.

AHN, OO.MM., leg. 6.110, n. $^{\circ} 2$, fol. 55r-56v.

Mandamyento para frey Pedro Véles de Jahén, comendador de Calatrava la Vieja./ 
Yo frey Pedro de Aguayo, comendador de Malagón, e yo frey Pedro/ de Troya, prior de San Benito de Sevilla, capellán de/ sus altesas visytadores generales de la Horden y cava-/ llería de Calatrava por los muy altos e muy podero-/ sos e christianísimos el rey e la reyna, nuestros/ señores, administradores perpetuos de ella/ por bula apostólica, fasemos saber a vos/ frey Pedro Véles de Jahén, comendador de Calatrava/ la Vieja, que visytando la dicha encomien-/ da fallamos que en El Turrillo donde solían estar/ las casas e aposentamientos de los comendadores que eran/ de la dicha encomienda ni en otra parte de ella no tenéys casas/ ni aposentamientos donde vos ni los comendadores después de vos/ que en la dicha encomienda suçedieren se aposenten, e por la/ relaçión que los visytadores pasados en el capítulo ge-/ neral se fiso en el fue acordado que fisyeres aposentamiento/ e casas en la villa de Carrión, pues es anexa a la dicha/ vuestra encomienda. Por ende, de parte de sus altesas/ y Horden, vos mandamos que en la dicha villa de Carrión,/ donde fue el capítulo general, fue acordado y nos pare-/ çió que asy hera justo, fagáys o compréys unas sus/ casas conforme a la calidad de la renta de vuestra enco-/ mienda en que vos y vuestros servidores buenamente/ podáys estar bien aposentados e según la cali-/ dad de vuestro estado y a tal persona como vos con-/ viene e como se espera que vos lo faréys las/ quales dichas casas daréys fechas e compradas segúnd/ e en la manera que dicho es en la dicha/ villa de Carrión desde el día de San/ Juan de junio primero que verná de la fecha de este juro mandamiento envyerno complido,/ prymero syguiente.//55v

E por que las poseyones de la Horden e las otras cosas/ pertenesçientes a la dicha vuestra encomienda mejor sean provey-/ das e aprovechadas y el patrimonio de la Horden conser-/ vado, de parte de sus altesas vos mandamos y de la/ nuestra encargamos, trabajéys de estar de asyento en la/ dicha vuestra encomienda de Calatrava la Vieja como se es/ obligado. E a los caballeros de la Horden que por ella/ pasaren los reçibir e aposentar caritativamente/ y en vuestra ausencia mandad a vuestro alcayde o mayordomo que asy lo cumpla e faga/ porque es mucha rasón e sus altesas asy/ lo tenían dado./

Otrosy syguiendo la regla de nuestro padre/ San Benito e la dotrina de nuestro padre San/ Bernaldo, en que nos enseña e muestra en rediesmo/ de nos toda propiedad la qual enbaraça al religioso/ subir al çielo. Por tanto de parte de sus altesas vos/ mandamos que en cada un año por la Semana Santa/ váys o enbiéys a pedir liçençia al pryor del convento/ de Calatrava para poseer los bienes que diese la/ Horden vos ha dado, asy los que avéys heredado de vuestro patrimonio como otros o qualquier más ayáys/ adquirido, como las difiniçiones de la Horden lo pre-/ miten y como sus altesas en el capítulo de Torde-/ sillas lo mandaron./ 
Y con esto todo lo que más vieredes que conviene al descar-/ go de vuestra conçiençia faréys e compliréys como persona/ çelosa de su Horden e en lo que vieredes que conviene/ de reparar en la dicha vuestra encomienda y creçer en las po-/ sesyones y heredades de ella con diligençia lo mires, / y porque todo sea mejor provyedo y reparado estar de/ asyento en la dicha vuestra encomienda como dicho es e non/ vades a dexar fuera de la comarca syno a cosas jus-/ tas e neçesarias de ella e de la Horden, e tener syen-/ pre con vos e en vuestras arcas todos los ynventarios/ claros de todas las heredades e rentas pertenesçien-/ tes a la dicha vuestra encomienda, asy algunos de los dichos bienes e posysiones y otras cosas supieredes estar enajenado con todas fuercas trabajar de lo redimir/ y cobrar porque la Horden no sea defraudada./

Otrosy de parte de sus altesas vos mandamos y en-/ cargamos que syenpre tengáys con vos y aderecadas/ y a punto las lanças con que sois obligado a servir por/ rasón de vuestra encomienda e de las quales toma$/ /{ }^{56 r}$ mos a la del como por sus altesas se mandó/ e determinó en el capítulo que se celebró en la/ çibdad de Granada. E fallamos que las tenéys/ adereçadas e apunto asy de cavallos como de las/ cosas nesçesarias segúnd que soys obligado.

E asymesmo tener con vos el manto del capítulo/ e las definiçiones e las leáys e vos/ ynforméis de ellas para las saber e/ conplir según e como en ellas se/contiene, espeçial la definiçión que/ defienden las concubinas y la que manda confesar e comulgar las tres/ Pasquas del año, e rreçibe çédulas de las confisyo-/ nes de los confesores de la Horden, las quales çedulas/ llevaréys o enviaréys al capítulo primero que sus/ mandaren a llevar con aperçibimiento, que syno las/ llevaredes o enviaredes pasaréys çinco florines/ por cada una ves que asy faltaredes como las di-/ finiçiones lo premiten. E tener syempre con/ vos el ynventario çierto e claro de vuestra dispusy-/ çión asy de bienes muebles como rayses por/ manera que a la Horden nada pueda ser encu-/ bierto e a tener cuydado de saber e complir/ las cosas acordadas en la espediçión de capítu-/ lo que sus altesas mandaron çelebrar en la çibdad/ de Granada, que fueron mostradas e amones-/ tadas a todas las personas de la Horden por/ quanto todo lo tal sus altesas quisieren y man-/ dan que se aya de guardar e complir e espeçial/ mente que resen todos los comendadores e cavalleros/ por oras e no de otra manera como por ella por/ tal está determinado que es como de horden/ tenemos e tener ayudado de pagar los flo-/ rines que por rasón del lienço en cada un año/ soys obligado allí donde de obligaçión tenéys./

Las quales cosas todas y cada una de las vos mandamos de parte de sus altesas y Horden/ que fagáys y compláys estante justo e legyti-/ mo 
ympedimiento o de otra manera será nes-/ cesario de proveer e remediar segúnd//56v los estatutos e definiçiones de la Horden lo dis-/ pone. E de lo quual mandamos dar e dimos este nuestro mandamiento fyrmado de nuestros nombres e del escribano/ de nuestra visytaçión cuyo traslado mandamos asentar/ en los libros de la que fecha en la villa de Almagro,/ a quinse días del mes de febrero de mill e quinientos/ e dos años.

Frey Pedro de Aguayo (rúbrica).

Prior de Sevilla (rúbrica).

Por merced de los señores visitadores, / Luys de Arévalo, escribano (rúbrica).

1510, febrero 20. Carrión

Sancho de Londoño, comendador de Torre del Cañaveral, y Rodrigo del Moral, prior de San Benito de Jaén, visitan la encomienda de Calatrava la Vieja.

AHN, OO.MM., leg. 6110, n. $^{\circ} 23$, fol. $82 r-83 r$.

20 de hebrero, El Turrillo y Calatrava la Vieja. 1510./

Visitaçión de la encomienda de Calatrava la Vieja que hallamos en los libros de la visi-/ taçión ser asyento e morada en El Turrillo./

En la villa de Carrión, veynte días del mes de hebrero,/ año del nasçimiento de nuestro Salvador Ihesuchristo de mill e/ quinientos diez años. Este día yo frei Sancho de Londoño,/ comendador de la Torre del Cañaveral, e yo frey Rodrigo/ del Moral, prior de San Benito de la çibdad/ de Jaén, visitadores generales de la Horden e/ cavallería de Calatrava, por el muy alto e/ muy poderoso el rey don Fernando, nuestro señor,/ administrador perpetuo de la dicha Orden por abto-/ ridad apostólica, venimos a ver y visitar las ca-/ sas y asiento de la encomienda de Calatrava la Vieja que/ son en El Turrillo, de que hallamos por comendador de ella/ a frei Pedro Vélez de Jaén, e fallamos todos los edifi-/ çios antiguos estantes y segúnd y de la manera que/ en los libros de la visitaçión pasada están asentados,/ çerca do qual se proveyó lo que adelante en nuestro manda/ miento será contenido.

Ynventario de los bienes, rentas y posisiones e otras cosas pertenesçientes a la enco-/ mienda de las Casas de Calatrava la Vieja que son en El Turrillo./ 
Primeramente tiene la dicha encomienda la dehesa de Calatrava de/ ynvierno y verano./

Pertenésçele el río de Guadiana e pesca quanto duran/ los términos de Calatrava./

Tiene que le pertenesçe las menuçias de Carrión./

Tiene más un ayantar en Carrión que a de dar el con-/ çejo de Carrión, ochenta maravedís cada un año.l

Tiene más la renta del lesparto que se saca a vender/ en hebra./

Pertenesçe más el pie de altar de Carrión y las penas y caloñas de las dehesas e términos de Calatra-/ va e Carrión./

Pertenesçe más poner el cura en la yglesia de Ca-/ rrión con benefiçiado de la dicha yglesia./

Pertenésçele más los mostrencos./

En Hernáncavaliero://82v

Tiene más que le an de dar en Hernáncavallero por otro/ ayantar çien maravedís e más cada veçino una gallina./

Pertenésçele más en el dicho lugar y sus términos los di-/ ezmos de los colmenares./

Pertenésçele más los diezmos de las primiçias que están en/ los colmenares en el término de Hernáncavallero./

Pertenésçele más penas y caloñas del dicho lugar./

Pertenésçele más el diezmo de lo que en los colmenares se co-/ brare y traere en la montarazía./

Pertenésçele más de cada res de monte que se pe-/ sare o matare en el dicho lugar, un arreal del./

Pertenésçele más la guarda de la montarazía/ que la puede arrendar para hazer carbón./

Pertenésçele más las penas y caloñaas e juegos/ del dicho lugar y los mostrencos./

Pertenésçele más la dehesa del Turrillo en la Çela-/ dilla y el medio diezmo del ganado que naçe e se cría/ en la dicha Celadilla, e los diezmos de las viñas de los/ veçinos de Carrión e Villa Real que están en término del Tu-/ rrillo, y la dehesa de la Çelada y las sernas del Turri-/ llo, de lo qual no goza el dicho comendador por razón que dize/ que se lo sacó la mesa maestral./ 
Demás de lo susodicho a conprado y au-/ mentado el comendador frey Pedro Vélez de Ja-/ én, comendador de la dicha encomienda, por/ propios e rentas de ella las cosas si-/ guientes./

Primeramente unas casas de aposento en la villa/ de Carrión que son çerca de la yglesia, alinde de casas/ de Juan Loçarro, el moço, e de Cristóbal, su sobrino./

Compró más el dicho comendador en la dicha villa, un quiñón/ de çinco hanegas de senbradura que es junto a San Se-/ vastián./

Compró más otro quiñón que cabe quatro hanegas de/ senbradura, alinde las de Bolaños./

Compró más el dicho comendador de Polo Pezca Retero, en el dicho lugar,/ un majuelo de mill y dozientos vides, li-/ nderos el camino del Cordovés./

Compró más del susodicho, otra viña de quatroçientas/vides en el mismo camino, linderos viña de Pedro Bueno./

Compró más en el çerro Caenca mill y quinientas vides/ de las de Bolaños, linderos Gonzalo de Pedro Fernándes y la Naranja/ Vieja.//83r

Compró más de Juan Sacristán, mill vides en la sierra, ca-/ mino de la çibdad que a por linderos Myguel Delgado./

Compró de Cristóbal Sobrino, otra viña de mill vides,/ camino el Cordovés, a por linderos Juan Sobrino./

Compró del susodicho otra viña çerca desta, camino/ el Cordovés, de mill vides./

Compró de los de Bolaños otra viña en la sierra de/ tres mill vides, a por linderos Martín Grande/ y el Carril.

1510, febrero 20. Carrión

Los visitadores Sancho Lendoño, comendador de Torre del Cañaveral, y Rodrigo del Moral, prior de San Benito de Jaén, mandan a Pedro Vélez de Jaén, comendador de Calatrava la Vieja, que mantenga en buenas condiciones los bienes de su encomienda y siempre que pueda los acreciente, tal y como lo habia hecho hasta entonces.

AHN, OO.MM., leg. 6.110, n. ${ }^{\circ} 23$, fol. $83 r-84 v$. 
Mandamiento para frei Pedro Vélez de Jaén, comendador de Calatrava la Vieja./

Yo frei Sancho de Lendoño, comendador de la Torre el Ca-/ ñaveral, e yo frei Rodrigo del Moral, prior de San Be-/ nito de la çibdad de Jaén, visitadores generales de la/ Horden e caballería de Calatrava, por el muy alto e/ muy poderoso el rey don Fernando, nuestro señor, ad-/ menistrador perpetuo de la dicha Orden por abtoridad/ apostólica, hazemos saber a vos frei Pedro Vélez de/ Jaén, comendador de Calatrava la Vieja, que vimos e visi-/ tamos la dicha vuestra encomienda e fallamos que las casas que vos fueron mandadas conprar en la visi-/ taçión pasada en la villa de Carrión, que aquellas/ avéis conprado, las quales son buenas e en buen/ sitio e tenéys començado a hazer en ellas un/ buen quarto nuevo que agora labráys, el/ qual acabado será la dicha casa buena y bien con-/ plida y con toda su casa de serviçio, e asimesmo/ hallamos que aviedes creçido en la dicha vuestra en-/ comienda çiertas tierras de quiñones e viñas,/ lo qual todo de parte de su alteza e Horden os/ agradeçemos e encargamos que sienpre a-/ sí hagáis por que la dicha vuestra encomienda cresca./

E porque las posisiones e otras cosas pertenesçientes a la dicha vuestra encomienda mejor sean pro-/ veídas e el pratimonio de la Horden conservado,/ de parte de su alteza e Horden vos mandamos y de/ la guesa encargamos que trabajéis de estar de/ asiento en la dicha vuestra encomienda como agora/ os fallamos para que los visitadores de la Orden/ puedan visitar vuestra persona.///33v

Otrosí siguiendo la regla de nuestro padre San/ Benito e dotrina de nuestro padre San Bernaldo, en/ que nos enseñan aredremos de nos toda propi-/ edad, la qual embaraça al religioso subir al çi-/ elo, por tanto de paresçer de su alteza e Horden os/ mandamos en cada un año por la Semana Santa/ vayáis o envíes a pedir liçençia al señor pri-/ or del convento de Calatrava para poseer los bie-/ nes que Dios y la Orden vos an dado, así/ los que viniere deseredado de vuestro patrim-/ onio, como otros en qualquier manera ayá-/ ys adquirido, como las difiniçiones de la/ Horden lo permitan e como su alteza e la Horden lo tiene mandado./

$\mathrm{E}$ con esto, todo lo que más vieredes que conviene/ al descargo de vuestra conçiençia faréis y con-/ plireis como persona zelosa de su Horden, y que lo/ que vieredes que conviene de reparar en la dicha vuestra/ encomienda e de creçer en las heredades e posi-/ siones de ella con diligencia lo mires, e por quanto/ do mejor sea proveydo e reparado estar de a-/ siento en ella e no vayáys lexos, fuera de la/ comarca de ella, sino a cosas justas e nesçesari-/ as a la dicha vuestra encomienda e Orden, e tener/con vos en vuestras arcas todos los ynventarios/ claros e de todas 
las eredades e rentas perte-/ nesçientes a la dicha vuestra encomienda, e si algu-/ nos de los dichos bienes e posesiones e otras/ cosas supieredes estar enajenadas, con toda/ diligençiia e con todas vuestras fuerças traba/ jar de los redimir e recabdar por que la dicha Orden no sea defradudada./

Otrosí de parte de su alteza os mandamos y en-/ cargamos que sienpre tengáis con vos adere-/ çadas e apunto las lanças con que soys obli-/ gado a servir por razón de vuestra encomienda, que/ son tres, después del capítulo que se çelebró en la çibdad........ Primeramente se fizo re-/ partimiento de las lanças que e cupo a la dicha vuestra/ encomienda de las dichas tres lanças, las quales fa-/ llamos que teniades para serviçio de su alteza cada y quando de ellas se quisiere servir.//84r

Asimesmo tener con vos el manto de capí-/ tulo e las difiniçiones e las leáys e vos yn-/ forméys de ellas para las complir segúnd e como/ en ellas se contienen, en espeçial la difiniçión/ que defiende las conqubinas e la que manda confe-/ sar e comulgar las tres Pasquas del año, e re-/ çebid çédulas de los confesores de la Orden don-/ de soys obligado, las quales llevares o/ enviares a capítulo general que su al-/ teza mandare çelebrar con aper-/ çibimiento, que sino las llevaredes o envia-/ redes pagaréis çinco florines por cada una/ vez que así faltaredes como las difiniçiones lo/ permiten. $E$ tened sienpre con vos el inventario de/ vuestra dispusiçión çierto e claro así de bienes mu-/ ebles como rayzes de manera que a la Horden nada/ pueda ser encubierto e tornéys cuydado de saber/ e complir las cosas acordadas en la esperiçión/ del capítulo que su alteza mando çelebrar en la vi-/ lla de Medina del Canpo, que fueron mostradas e amonestadas a todas las personas de la Horden./ Por quanto todo lo tal su alteza quiere e manda que/ se aya de guardar e complir espeçialmente,/ que es razón todos los comendadores e caballe-/ ros por oras y no de otra manera como por el capítulo está determinado que es como de Orden tenemos./

Otrosí vos mandamos que gastéys los flo-/ rines que por razón del lienço soys obligado/ a gastar e los gastéys en los lugares donde/ la bula que para esto fue conçedida a la dicha Horden lo dispone dende el año de mill e quinientos e/ un año a esta parte./

Las quales dichas cosas e cada una de ellas de parte/ de su alteza e Horden vos mandamos que hagá-/ ys e compláis estante justo e legítimo yn-/ pedimento, de otra manera será neçesario de lo prove-/ er e remediar segúnd los estatutos de la Horden lo dispone. De lo qual mandamos dar e dimos este nuestro mandamiento firmado de nuestros / nombres e del escribano de nuestra visitaçión que yso//84v traslado mandamos asentar en los libros de ella que es fecha en la villa de Carrión, a veynte días/ del mes de hebrero de mil e quinientos e diez años./ 
Frey Sancho de Lendoño (rúbrica).

Frey Rodrigo (rúbrica).

Por mandado de los señores visitadores,/ Jorge Serrano, escribano/ mayor de su alteza (rúbrica).

1510, febrero 20. Carrión

Pedro Vélez de Jaén, comendador de Calatrava la Vieja, realiza la valoración de la rentas de su encomienda, tanto en dinero como en especie, relativa al año 1509.

AHN, OO.MM., leg. 6.110, n. ${ }^{\circ} 23$, fol. 88r.

Calatrava la Vieja. Año 1510./

Relaçión de los maravedís, pan, trigo e çebada e otras cosas que valyó la encomyenda de Calatrava/ la Vieja el año pasado de mill e quinientos e nueve años./

Valyó la yerba de la dehesa de Calatrava este/ dicho año ante allozar e el trigo de yn-/ vierno e angostadero e noventa e tres mil/ maravedís./

Valyó este año los corderos treze mil e seysçientos/maravedís e la lana catorze mill e quinientos e treynta maravedís que/ son todos veynte e ocho mil e çiento e treynta maravedís./

Valyó el diezmo de moços y potras e bezerros/ y las otras menudençias seys mil maravedís./

Rentó la pesca del río dos mil e seteçientos maravedís,/ doze arreldes de peçes./

Tiene la dicha encomienda en los conçejos de Carrión e/ Hernáncavallero çiento e ochenta maravedís./

Tuvo este año de los vesinos de Hernáncavallero treynta/ gallinas, porque cada vesyno le ha de dar una/ gallina./

Asy que montan los maravedís e gallinas e arredes de peçes/ que ha valydo la dicha encomienda el dicho año $\mathrm{C} /$ treynta mil e diez maravedís e treynta gallinas e doze/ arreldes de peçes segúnd que lo dio e mando frey Pedro/ Vélez de Jahén, comendador de la dicha encomyenda, e por que/ asy verdad lo firmo de su nombre que es fecha en la villa/ de Carrión, a veynte días de febrero de mill e quinientos/ e diez años.

Frey Pedro Vélez de Jaén (rúbrica). 